\title{
Verge: A Novel Vascular Early Response Gene
}

\author{
Jean B. Regard, ${ }^{1}$ Sigrid Scheek, ${ }^{5}$ Talaibek Borbiev, ${ }^{4}$ Anthony A. Lanahan, ${ }^{1}$ Armin Schneider, ${ }^{5}$ \\ Anna-Maria Demetriades, ${ }^{3}$ Holger Hiemisch, ${ }^{5}$ Carol A. Barnes, ${ }^{6}$ Alexander D. Verin, ${ }^{4}$ and Paul F. Worley ${ }^{1,2}$ \\ Departments of ${ }^{1}$ Neuroscience, ${ }^{2}$ Neurology, and ${ }^{3}$ Ophthalmology, ${ }^{4}$ Division of Pulmonary and Critical Care, Johns Hopkins University, Baltimore, Maryland \\ 21205, ${ }^{5}$ Axaron Bioscience, 69120 Heidelberg, Germany, and ${ }^{6}$ Departments of Psychology and Neurology, University of Arizona, Tucson, Arizona 85724
}

Vascular endothelium forms a continuous, semipermeable barrier that regulates the transvascular movement of hormones, macromolecules, and other solutes. Here, we describe a novel immediate early gene that is expressed selectively in vascular endothelial cells, verge (vascular early response gene). Verge protein includes an $\mathrm{N}$-terminal region of $\sim 70$ amino acids with modest homology ( $~ 30 \%$ identity) to Apolipoprotein L but is otherwise unique. Verge mRNA and protein are induced selectively in the endothelium of adult vasculature by electrical or chemical seizures. Verge expression appears to be responsive to local tissue conditions, because it is induced in the hemisphere ipsilateral to transient focal cerebral ischemia. In contrast to the transient expression in adult, Verge mRNA and protein are constitutively expressed at high levels in the endothelium of developing tissues (particularly heart) in association with angiogenesis. Verge mRNA is induced in cultured endothelial cells by defined growth factors and hypoxia. Verge protein is dramatically increased by cysteine proteinase inhibitors, suggesting rapid turnover, and is localized to focal regions near the periphery of the cells. Endothelial cell lines that stably express Verge form monolayers that show enhanced permeability in response to activation of protein kinase $\mathrm{Cby}$ phorbol esters. This response is accompanied by reorganization of the actin cytoskeleton and the formation of paracellular gaps. These studies suggest that Verge functions as a dynamic regulator of endothelial cell signaling and vascular function.

Key words: immediate early gene; IEG; endothelial cell; vascular permeability; seizure; ischemia; middle cerebral artery occlusion; MCAO; stroke model; electrical cell-substrate impedance sensing; ECIS; transendothelial resistance; TER; protein kinase C; PKC; fibroblast growth factor 2; FGF2; tumor necrosis factor $\alpha$; TNF- $\alpha$; vascular endothelial growth factor; VEGF; hepatocyte growth factor; HGF; angiopoietin 1; Ang-1; angiopoietin 2; Ang-2

\section{Introduction}

Vascular endothelium forms an interface that defines intravascular and extravascular compartments and serves to regulate the exchange of fluid, solutes, and cells (Klagsbrun, 1996; Majesky, 2001). Impairment of endothelial barrier function results in the development of tissue edema and contributes to the pathogenesis of many illnesses, including stroke, acute respiratory distress syndrome (ARDS), and sepsis (Bernard et al., 1994; Bannerman and Goldblum, 1999; van Soeren et al., 2000). Significant progress has been made in understanding the molecular and cellular mechanisms that account for endothelial barrier function (Lum and Malik, 1996; Dudek and Garcia, 2001). A major mechanism accounting for inflammation-induced increased vascular permeability is increased paracellular permeability resulting from changes in cell shape, loosening of endothelial cell-cell contacts, and the formation of inter-endothelial gap, events shown to be critically dependent on regulation of the actin cytoskeleton (Lum and Malik, 1996; Dudek and Garcia, 2001; Vogel et al., 2001; Minshall et al., 2002). Such events are induced by bioactive mol-

Received Sept. 17, 2003; revised March 15, 2004; accepted March 17, 2004

This work was supported by National Institutes of Health Grant AG09219 (C.A.B., P.F.W.) and by German Federal Ministry of Education and Research Bioregio Grant 0312748 to Axaron.

Correspondence should be addressed to Dr. Paul F. Worley, Johns Hopkins University, 725 North Wolfe Street, Hunterian Building, Room 905, Baltimore, MD 21205. E-mail: pworley@jhmi.edu.

D01:10.1523/JNEUROSCI.4252-03.2004

Copyright $\odot 2004$ Society for Neuroscience $\quad$ 0270-6474/04/244092-12\$15.00/0 ecules such as thrombin, tumor necrosis factor $\alpha$ (TNF $\alpha$ ), phorbol 12-myristate 13-acetate (PMA), or $\mathrm{H}_{2} \mathrm{O}_{2}$ and have been documented in vivo as well as in cultured endothelial cells (Majno and Palade, 1961; Majno et al., 1969; McDonald et al., 1999). Although the signaling pathways associated with these cellular changes remain unclear, the protein kinase $\mathrm{C}$ (PKC) family has been implicated as a key regulator (Lum and Malik, 1996; Dudek and Garcia, 2001).

In the present study, we report a novel gene that is selectively expressed in endothelial cells and is regulated as an immediate early gene (IEG). We term this gene verge for vascular early response gene. Verge mRNA is rapidly and transiently induced in mature, quiescent vasculature and is highly expressed during developmental angiogenesis. Functional studies that examine endothelial cell monolayer permeability indicate that Verge alters the response of endothelial cells to activation of PKC. Our observations suggest that Verge functions to dynamically regulate PKC-dependent signaling that leads to reorganization of the actin cytoskeleton and alterations of vascular permeability.

\section{Materials and Methods}

Reagents. PMA, human recombinant fibroblast growth factor (FGF), RNase A, kainic acid, pentylene tetrazole (PTZ), thrombin, transforming growth factor- $\beta$ (TGF- $\beta$ ), and horseradish peroxidase-conjugated Bandeirae Simplicifolia lectin (BS-1) were purchased from Sigma (St. Louis, MO). Angiopoietin-1 (Ang-1), angiopoietin-2 (Ang-2), and hepatocyte growth factor (HGF) were purchased from R \& D Systems (Minneapolis, 
MN). U0126, bisindolylmaleimide I (BIM), SB203580, Calpain inhibitor I (ALLN), and Calpain inhibitor II (ALLM) were obtained from Calbiochem (La Jolla, CA)-Novabiochem (San Diego, CA). 4',6-diamidino-2phenylindole, dihydrochloride (DAPI) and mouse monoclonal antibody $(\mathrm{Ab})$ against hemagglutinin (HA) were purchased from Roche Diagnostics (Mannheim, Germany). Fluorescent secondary antibodies were purchased from Jackson ImmunoResearch (West Grove, PA). Fluorescein isothiocyanate (FITC)-labeled phalloidin was purchased from Molecular Probes (Eugene, OR).

cDNA subtraction and isolation of full-length verge cDNA. A subtracted cDNA library was constructed as described previously (Yamagata et al., 1993). Full-length verge cDNA clones were isolated by screening an unsubstracted, oligo (dT)-primed cDNA library prepared from the hippocampus of rats that had been given cycloheximide $(20 \mathrm{mg} / \mathrm{kg})$ and $4 \mathrm{hr}$ of multiple maximal electroconvulsive shock (MECS).

Northern blot analysis. Total RNA was isolated using standard $\mathrm{CsCl}$ density centrifugation and assayed for purity and yield by ultraviolet spectroscopy. Ten micrograms of RNA per lane was subjected to denaturing agarose gel electrophoresis. Gels were stained with ethidium bromide, and the ribosomal bands were visualized to assess equal loading of RNA. After transfer to Hybond $\mathrm{N}^{+}$nylon membranes, Northern blot analysis was performed with a probe corresponding to the open reading frame (ORF) of rat verge or to a $2070 \mathrm{bp}$ Xhol/HindIII cDNA fragment of human Verge. A probe for glyceraldehyde-3-phosphate dehydrogenase (GAPDH) was used as an RNA loading control. Quantification of the hybridization signal was performed using the Typhoon imaging system (Amersham Biosciences, Piscataway, NJ) and normalized to GAPDH.

Generation of anti-Verge antibodies. Synthetic peptides representing the $\mathrm{N}$-terminal and C-terminal 22 amino acids of the rat Verge were conjugated to thyroglobulin (m-maleimidobenzoyl- $N$-hydroxysuccinimide ester; Pierce, Rockford, IL) and used as immunogens in rabbits (Covance, Princeton, NJ). Rabbit polyclonal Abs were similarly generated using a glutathione $S$-transferase (GST) fusion protein containing the C-terminal 73 amino acids of rat Verge (Covance). Rabbit polyclonal antibodies were similarly generated using human Verge sequences. Human Verge peptides comprising amino acids 3-21 [Ab 30, 36-51 (Ab 25), and 230-248 (Ab 23)] were conjugated via an additional cysteine to keyhole limpet hemocyanin (Biotrend Chemikalien GmbH, Koln, Germany).

Isolation of rat brain microvessels. Capillary segments were isolated from PBS-perfused rat brain as described previously (Goldstein et al., 1975). Isolated microvessels were air dried onto superfrost plus-coated slides (VWR Scientific Products, West Chestire, PA) and stored at $-20^{\circ} \mathrm{C}$ before analysis.

In situ hybridization. Colorimetric in situ hybridization was performed on fresh-frozen sectioned tissue using nonradioactive digoxigeninlabeled cRNA probes and 5-bromo-4-chloro-3-indolyl phosphate/nitroblue tetrazolium (Roche) colorimetric detection as described previously (Blackshaw and Snyder, 1997). Fluorescent in situ hybridization was performed using identical hybridization and wash conditions as for colorimetric in situ. Fluorescent-tyramide kit (NEN, Boston, MA) was used for detection.

Immunohistochemistry. Brains were removed from control rats or rats treated for $2 \mathrm{hr}$ with kainic acid (11 mg/kg, i.p.). Brains were frozen in optimal cutting temperature compound (Sakura, Tokyo, Japan) and sectioned at $20 \mu \mathrm{m}$ on superfrost-coated slides. Sections were immersion fixed in 3.7\% paraformaldehyde (PFA; in PBS, pH 7.4) for $10 \mathrm{~min}$, permeabilized for $15 \mathrm{~min}$ in $0.25 \%$ Triton X-100/PBS, and then treated for 15 min with $3 \% \mathrm{H}_{2} \mathrm{O}_{2}$. Antigen retrieval was performed by placing the slides in $100 \mathrm{~mm}$ Citrate, $\mathrm{pH} 4.0$, and heating to $\sim 95^{\circ} \mathrm{C}$ by microwave for $30 \mathrm{sec}$. Slides were blocked with $10 \%$ normal goat serum (NGS) in PBS at room temperature. Primary Ab was added to the slides and incubated at $4^{\circ} \mathrm{C}$ overnight. Slides were washed thoroughly, and bound antibodies were detected using $\mathrm{ABC}$ kit (Vector Laboratories, Burlingame, $\mathrm{CA}$ ) followed by DAB (Sigma) colorimetric staining.

Cell culture and transfection. Primary endothelial cells from adult mouse lung and heart were isolated as described previously (Allport et al., 2002). Neonatal human dermal microvascular endothelial cells (HMVECs) were purchased from Cambrex BioScience (Walkersville, MD) and cultured in the endothelial growth medium 2-microvascular
(EGM2-MV) media from the manufacturer, supplemented with EGM2 single quots. Rat brain endothelial cell line 4 (RBE4) cells have been described previously (Roux et al., 1994) and were a generous gift from John Laterra (Johns Hopkins University, Baltimore, MD). These cells were grown on gelatin-coated tissue culture dishes in RBE4 media (DMEM, 10\% fetal bovine serum (FBS), 1\% penicillin-streptomycin, 20 mM HEPES, pH 7.4, and $1 \mathrm{ng} / \mathrm{ml}$ hrbFGF). Stable cell lines were established that express $5^{\prime}$-HA-Verge transgene. For transfection, the plasmids pRK5-5'HA-Verge and pPUR (containing the puromycin resistance gene; Clontech, Palo Alto, CA) were mixed together in a molar ratio of 10:1. RBE4 cells were electroporated with this plasmid mixture and allowed to recover for $48 \mathrm{hr}$. Stably transfected cells were selected with 10 $\mu \mathrm{g} / \mathrm{ml}$ puromycin (Clontech) and screened for transgene expression by Western blot analysis. Four stable lines were selected and termed clones $2,38,41$, and 42 . Nontransgene-expressing, puromycin-resistant clones were also selected as negative controls (termed clones A and B). COS-1 cells were purchased from American Type Culture Collection (Manassas, VA) and grown in DMEM, 10\% FBS, and 1\% penicillin/streptomycin and were transiently transfected using calcium phosphate.

Hypoxia treatment. HMVECs of passage 6 were seeded with $1.2 \times 10^{6}$ cells per $10 \mathrm{~cm}$ dish and grown to confluence in supplemented EGM2-MV media. On day 4, cells covered by $3 \mathrm{ml}$ of medium per plate were placed into a $37^{\circ} \mathrm{C}$ tempered hypoxia chamber. For catalytic removal of residual oxygen, a package of BBL GasPak replacement charges (Becton Dickinson, Cockeysville, MD) was placed into the chamber and then it was constantly floated with a mixture of $\mathrm{N}_{2}$ (90\% volume), $\mathrm{CO}_{2}$ (5\% volume), and $\mathrm{H}_{2}$ (5\% volume) at $37^{\circ} \mathrm{C}$. Plates were removed from the chamber at indicated time points, and RNA preparation and Northern blot analysis was performed as described.

Immunofluorescence. HMVECs of passage 8 were grown on fibronectin-coated glass coverslips. Cells were washed three times with PBS and fixed for $15 \mathrm{~min}$ at $37^{\circ} \mathrm{C}$ in $4 \% \mathrm{PFA}$ in PBS. Cells were rinsed twice with PBS and washed three times for 5 min with glycine $(50 \mathrm{~mm}) /$ PBS. After permeabilization on ice with $0.15 \%$ Triton X-100/PBS for 7 min, cells were blocked with $2 \%$ NGS/PBS for $1 \mathrm{hr}$ at room temperature. Incubation with anti-Verge antisera was performed in a 1:200 dilution in $1.5 \%(\mathrm{v} / \mathrm{v}) \mathrm{NGS} / \mathrm{PBS}$ for $2 \mathrm{hr}$ at room temperature. Cells were washed four times with washing buffer [1.5\% (v/v) NGS, $100 \mathrm{~mm} \mathrm{NaCl}, 10 \mathrm{~mm}$ Tris-HCl, pH 7.6] and incubated with FITC-anti-rabbit IgG for $1 \mathrm{hr}$. Cells were washed three times for $5 \mathrm{~min}$ with washing buffer, three times with PBS, and rinsed four times with Tris- $\mathrm{HCl}(10 \mathrm{~mm}, \mathrm{pH}$ 7.6). Coverslips were mounted with Aqua Poly/Mount (Polysciences, Warrington, PA), and cells were visualized using a confocal Leica (Bensheim, Germany) microscope.

Electrical cell-substrate impedance-sensing experiments. RBE4 cells were grown to confluence on small gold electrodes (Applied Biophysics, Troy, NY) in RBE4 media (Tiruppathi et al., 1992; Verin et al., 2000; Garcia et al., 2001). Electrical resistance of endothelial cell monolayers was measured with an electrical cell-substrate impedance-sensing (ECIS) system (Applied Biophysics). Before experimentation, cells were incubated with fresh media, and resistance across the resting monolayer was monitored for $1 \mathrm{hr}$ to ensure a stable baseline. A $4000 \mathrm{~Hz}$ AC signal with a $1 \mathrm{~V}$ amplitude was applied to the RBE4 monolayer through a $1 \mathrm{M} \Omega$ resistor, creating an approximate constant-current source of $1 \mu \mathrm{A}$. The small electrode and larger counter electrode $\left(1 \mathrm{~cm}^{2}\right)$ are connected to a phasesensitive lock-in amplifier with a built-in differential preamplifier (5316A; EG \& G Instruments, Princeton, NJ). The in-phase and out-ofphase voltages between the electrodes were monitored in real time with the lock-in amplifier and were converted to scalar measurements of transendothelial impedance. Resistance values from each microelectrode (measured in ohms) were normalized as the ratio of measured resistance to baseline resistance and plotted versus time and statistically assessed using Epool software, kindly provided by Dr. K. L. Schaphorst (Johns Hopkins University School of Medicine, Baltimore, MD). At time 0, either agonist or vehicle was added to the cells, and resistance was assayed over the course of several hours. Resistance data were normalized to the initial voltage and plotted as normalized resistance. An independent $t$ test was performed to analyze the differences between means of electrical 
resistance. Results are expressed as means \pm SD. Differences in two groups are considered statistically significant when $p<0.05$.

Focal cerebral ischemia model. For middle cerebral artery occlusion and reperfusion, the filament model was used as described previously (Schneider et al., 1999).

Quantitative PCR. cDNA was synthesized using oligo-dT primers and Superscript II reverse transcriptase (RT) and purified by using silicabased columns (Qiagen, Hilden, Germany). Quantitative PCR was performed using the LightCycler system (Roche) as described previously (Brambrink et al., 2000). In brief, cDNAs were serially threefold diluted to obtain four to five concentration points for quantification. The concentrations of genes of interest in different cDNA samples were normalized to levels of the housekeeping gene cyclophilin; $60^{\circ} \mathrm{C}$ was chosen as the annealing temperature. Measurements of cyclophilin and Verge amplicons were performed at $84^{\circ} \mathrm{C}$ to exclude potential PCR by-products from the analysis. The following primers were used for PCR amplification: cyclophilin: cyc5(s), 5'-ACCCCACCGTGTTCTTCGAC-3'; acyc300(as), 5'-CATTTGCCATGGACAAGATG-3', Verge: 119-17(s), 5'-GGGTCTGAATAGGAA GGGAGTCTG-3'; L119-19(as), 5'-ATAGGACATCAGGTTTCCAAGGTC- $3^{\prime}$. The specificity of the PCR reaction was checked by determining the melting point and by size using agarose gel electrophoresis. Values were averaged from at least three different dilution measurements per sample and are given as means \pm SD.

\section{Results}

\section{Verge is a novel immediate early gene}

We used a differential cloning strategy to identify mRNAs that are rapidly induced in rat brain by electrical seizure (Yamagata et al., 1993). A novel cDNA (verge) corresponding to a $\sim 3.0 \mathrm{~kb}$ mRNA was isolated, and three independent full-length cDNAs were sequenced. The size of the full-length verge cDNA (2947 bp) corresponds closely to the estimated size of the rat mRNA identified by Northern blotting (Fig. 1A). The longest ORF with an initiator methionine predicts a protein of 246 amino acids. This initiator methionine is an acceptable Kozak consensus sequence (Kozak, 1981) and is downstream of an in-frame stop codon (Fig. 2A). The $3^{\prime}$ noncoding region contains eight AUUUA (ATTTA in cDNA) mRNA instability motifs (Shaw and Kamen, 1986). The predicted molecular mass of rat Verge is $26.8 \mathrm{kDa}$, and the $\mathrm{pI}$ is 9.60 . Analysis of Verge amino acid sequence predicts an N-terminal leucine-zipper motif (amino acids residues 15-43), two regions of hydrophobicity [amino acids residues 50-97 and 157-179, as predicted using the TMpred program (Kyte and Doolittle, 1982)], and a C-terminal coiled-coil domain [amino acid residues $188-240$ predicted by the Lupas method (Lupas et al., 1991)] (Fig. 2B). There are several predicted phosphorylation sites including a PKC site at residue 153 and PKA sites at residues 50 and 237.

Verge sequences and predicted ORFs were subsequently identified for both mouse and human in the National Center for Biotechnology Information database (NCB AX_665396 and NM_030817, respectively), and three independent mouse cDNAs obtained by screening a brain library were confirmed to match the NCBI database. The human verge mRNA is $\sim 4.7 \mathrm{~kb}$ and encodes an ORF predicted to be 248 amino acids, with two additional amino acids at the $\mathrm{N}$ terminus. The amino acid residues are $87 \%$ identical between rat, mouse, and human species (Fig. 2B).

Basic Local Alignment Search Tool (BLAST) analysis of the verge ORF identified several proteins that contain regions of modest homology (Fig. 2C). In mammals, all six members of the apolipoprotein L (ApoL) family (NP_003652.2, NP_6663612.2, XP_235464.1, NP_085146.2, NP_085145.1, NP_085144.1) encode a $\sim 70$ amino acid region that is homologous to Verge. Two putative Fugu rubripes proteins (NCBI accession numbers SINFRUP053682 and SINFRUP055309) and two putative C. el-
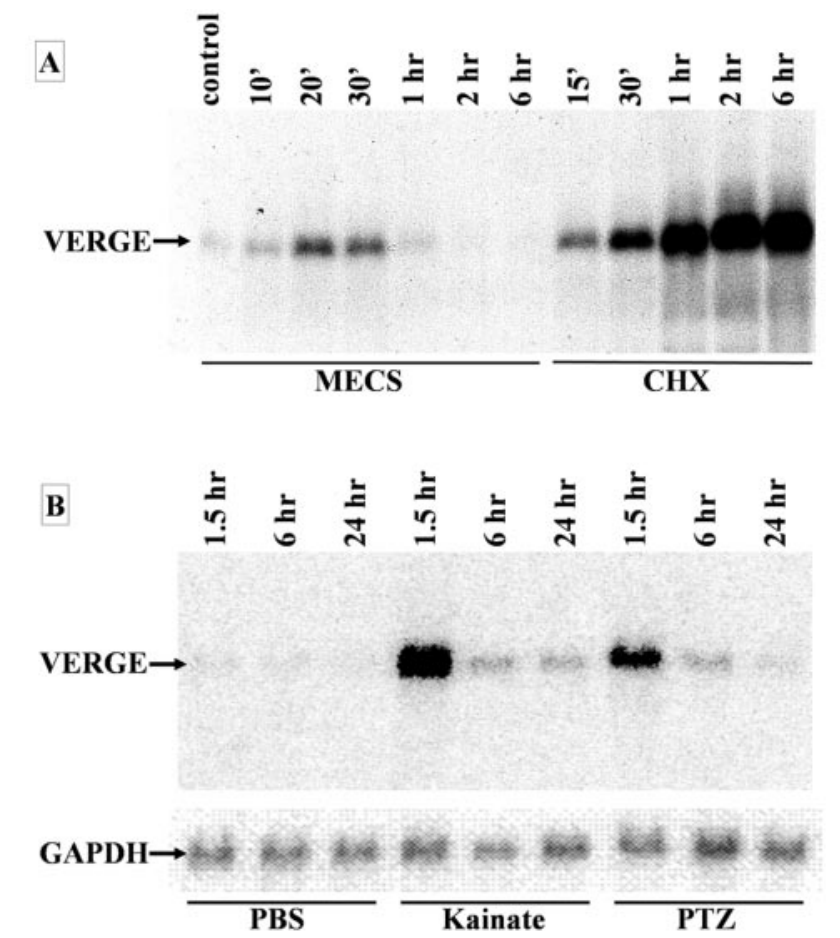

Figure 1. Verge mRNA is induced by seizures and cycloheximide in rat brain. A, RNA was isolated from hippocampi of control rats or rats treated with either a single MECS or cycloheximide ( $20 \mathrm{mg} / \mathrm{kg}$, i.p.) and killed at the indicated time. Northern blot analysis was performed on $10 \mu \mathrm{g}$ of total RNA using ${ }^{32} \mathrm{P}$-dCTP-labeled rat verge ORF as a probe. $B$, Rats received an intraperitoneal injection of PBS, kainic acid (11 mg/kg), or PTZ (50 mg/kg) and were killed at the indicated time points. RNA was isolated from hippocampi. Northern blot analysis was performed on $10 \mu \mathrm{g}$ of total RNA using ${ }^{32} \mathrm{P}$-dCTP-labeled rat verge ORF as a probe. A probe for GAPDH was used as a control for RNA loading.

egans proteins (NCBI accession numbers T15963 and NP_740988.1) also show homology to Verge. One of the F. rubripes proteins (SINFRUP053682) appears to be a fish homolog of mammalian ApoL, and the second F. rubripes protein (SINFRUP055309) appears to be a partial sequence. In all cases, homology is limited to amino acid residues 35-108 of Verge (Fig. $2 C)$. Within this region, Verge shows 30\% identity $/ 55 \%$ amino acid homology with the ApoL family members, 30\% identity/ 61\% homology with F. rubripes (SINFRUP055309), and 25\% identity $/ 42 \%$ homology with $C$. elegans. In comparison, members of the ApoL family show $\sim 50 \%$ identity $/ 72 \%$ amino acid homology in this region with each other and 30\% identity $/ 50 \%$ homology with the putative F. rubripes or C. elegans proteins. PsiBlast analysis did not identify additional proteins that contain the putative ApoL domain.

Analysis of expressed sequence tag (EST) and serial analysis of gene expression (SAGE) databases revealed verge mRNA to be abundantly expressed in a large number of tissues sources, including fetal tissues, placenta, and solid tumors (data not shown). BLAST analysis indicates that the genomic location of human verge is chromosomal position $12 \mathrm{p} 13.2$.

\section{Verge is rapidly induced in endothelial cells of cerebral} vessels by seizures

Verge mRNA expression was analyzed for regulation by seizure evoked by MECS or by chemical inducers of seizures, including kainic acid and PTZ. We also examined the dependence of verge mRNA induction on de novo protein synthesis using cycloheximide, which blocks protein translation (Rajagopalan and Malter, 
A

ATTCGGCACGAGCCAGAGTGA

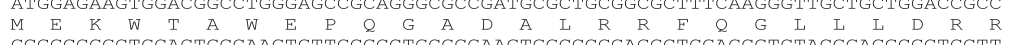
$\begin{array}{lllllllllllllllllllllll}G & R & L & H & C & Q & V & L & R & L & R & E & V & A & R & R & L & E & R & L & R & R & S\end{array}$ GGCAGCCAACGTAGCTGGCAGCTCTCTGAGCGCTGCTGGCGCCCTAGCAGCCATCGTGGGGTTATCACTCAGCCCG

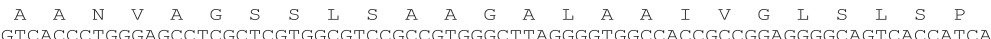

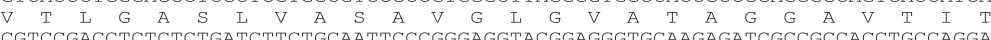
$\begin{array}{ccccccccccccccccccccccccc}S & D & L & S & L & I & F & C & N & S & R & E & V & R & R & V & Q & E & I & A & A & T & C & Q & D \\ C & \end{array}$

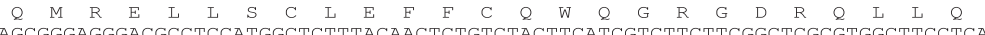
AGCGGGAGGGACGCCTCCATGGCTCTTTACAACTCTGTCTACTTCATCGTCTTCTTCGGCTCGCGTGGCTTCCTCA $\begin{array}{llllllllllllllllllllllllll}S & G & R & D & A & S & M & A & I & Y & N & S & V & Y & F & I & V & F & F & G & S & R & G & F & L & I\end{array}$

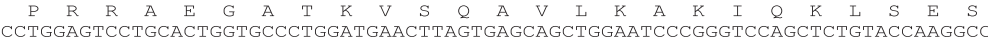
CCTGGAGTCCTGCACTGGTGCCCTGGATGAACTTAGTGAGCAGCTGGAATCCCGGGTCCAGCTCTGTACCAAGGCC $\begin{array}{cccccccccccccccccccccccc}L & E & S & C & T & G & A & L & D & E & L & S & E & Q & L & E & S & R & V & Q & L & C & T & K \\ \text { GGCCGTGGTCACAACCTCAGGAACTCCCCTGATCTGGATGCAGCGTTGTTTTTCTAAGAGCATCCTCTAGCTGTGT }\end{array}$

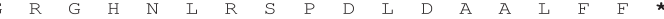

GGAATGTTCTAGATTCGCAGCATCCACAAGGAAGTGCTACATGGGCGGAGTGCAAAGGATTTCAGAAGCTCTTCTT CAGGGCATCAGTCCGTAGCTCCTTGTGTGTGCGAAAGACTTTTCACTTGTGTAATCCCAACTGAGTATGTGACCCTA AACAGTCACTTTGGGGACTCCCCAAATCCTTTTTAGCTGCACACAGCTTGTCAGACTGTCCTTCAATTAGAGTTATT GGGGTGGGGGGGCTTGATGGCTTGAGTAATAGAGGTCTGGCGAGGTGTCTCCCTCTTGGACCTCTTATGTGTTGTTA CTAGAATCCTGAGATTCTCAAATGTTGGTGAGAGGAGACTTTTACTTTTCAACTTTGCTTCGGCAGTTTCCGATACA CAGGACTCCAGAATCCAGAACAAGAAAGAAGAACCTTGTGTTTGTAGGGTGTGCAGACCCAGACGGGGCCGAGGAGC TGACTTGCTCAGCTCTCACACGCAGCCAGTTTATCCACTCACAGACCAAACCTGGCTACTGCATAGACTGTTCCAGT GTGGCTTCAAATCCACACCTCTAGGTACCCTGAGAAGGAAAGCCACCTGAAGAGTCACTCTAATCCCAACACGCTCA CCCCCTTCACGTCCATAAAGGAGCTGGGCAAGGGGTGAGATGAAGACCCTGACAATTTTAAATGACTGTAGCATAGA GAGCCATGGCCTTTGAGTTTAAGAGTCTTGATCCCAGGTTCTGTCCCCCACTGTCCTGTGACTTAGCCACCTTGTC' TGCTACAGATGGTGGTAGGAGGCCACCCTGTTGCGAAGTCCTGAGATAATGACAAACACAGAGGCTAGCTCACAAAA ATGTACTTCCTGGCCTGGCTTCTGAAGGGTTAACTGTTGGGCTCCATCCCAGATTTCTGAGATCAGGAACTCCAAA' ATGAGGCCCGCCTCTGGCTGATTCTGATGCCCCATAAATGTTTGAAAATGACACAGCAAAGGTTCATCTCCAGCCAG GTGTGGTGGGACACACCTGTAAGGCCAGCGCTTGGAGATGGAGACAGGGGGACCAGTAGTTCAGGGTCATTCTTGGC TACATAGCAAACICAAGGCCACCCTGGTCTCAAAAACCAAAACAAAAAGCCATCTTCTGACTCCCTTCAATTGTTCA AAGCCTTICCAGGGCCTTCAGAATCACGCTCAGAGTGTTCTGGGAAGATTAGCCCAGAAGCCAGAGAAAGAGTACGC

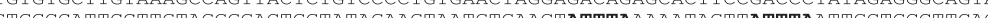
GTGCCATTCCTIGTAGGGGACTGGTATAGAAGTAATGTGAAC TATTAAAAAATAGTTATTTAATTGCTGCCTTCAC

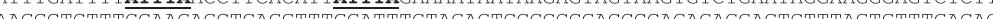

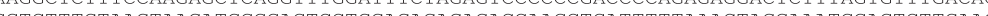

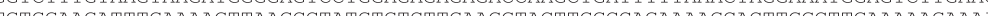
CCTGTTTAATTCAGGGGTGGAGGAATAGAGACAGATGAR

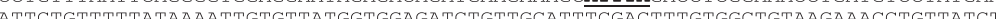
作 A GCCTGTCGTCTCTCTGA GATAATGGTGTGTCTGAGGAAATGTAAGTTTGGCATGAGGGGGAGGGGCTGCTGTTTC

\section{B}

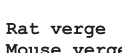

Mouse verge

Rat verge

Mouse verge

Human verge

Rat verge

Mouse verge
Human verge

Rat verge

Mouse verge

Human verge

Rat verge

Mouse verge
Human verge

C

Hu-verge

Hu-apo-L6

Fugu-53682

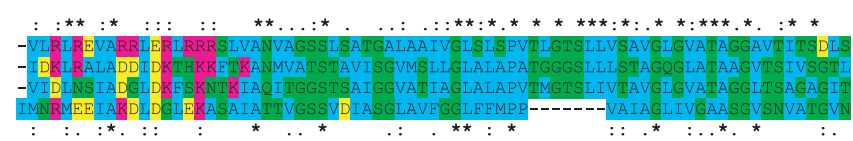

Figure 2. Nucleotide and amino acid sequences for verge and protein homologies. $A$, Rat verge nucleotide and amino acid sequence. Numbers to the right refer to the last nucleotide in each line. ATTTA mRNA instability signals are bold and underlined. $B$, Rat, mouse, and human Verge proteins show $87 \%$ amino acid identity. The conserved N-terminal leucine zipper motif is indicated by ZZ above the alignment, and C-terminal coiled-coil domain is identified by CC above the alignment. The region of homology with ApoL proteins is indicated by $==$. Sequence coloring is based on ClustalW: blue, small and hydrophobic; green, hydroxyl plus amine plus basic $Q$ plus cysteine residues; yellow, acids; magenta, bases; *, identical; :, conserved substitution; ., semi-conserved substitution. C, Multiple sequence alignment of human Verge (amino acids 35-108), human ApoL6 (amino acids 57-130), putative $f$. rubripes protein 53682 (amino acids 18-91), and putative C. elegans protein NP 740988 (amino acids $936-1004)$. Coloring and symbols are the same as in B. Symbols above alignment represent homology of Verge and ApoL6. Symbols below alignment show homology of all proteins.
1996). Northern blot analysis demonstrates that both MECS seizure and cycloheximide induce verge mRNA (Fig. 1A). Induction by MECS is rapid and transient with peak mRNA expression occurring 20-30 min after seizure. Verge mRNA expression returns to baseline by $1 \mathrm{hr}$. Induction by cycloheximide is also rapid but continues up to $6 \mathrm{hr}$ (final time point) after administration. The level of verge mRNA after $6 \mathrm{hr}$ of cycloheximide is estimated to be $\sim 20$-fold higher than the peak level induced by MECS (Fig. 1A). Similarly, treatment of rats with the epileptogenic excitatory amino acid kainic acid (15 $\mathrm{mg} / \mathrm{kg}$, i.p.) or PTZ (50 mg/kg, i.p.) resulted in a rapid transient induction of verge mRNA in brain (Fig. $1 B$ ). This temporal pattern of induction by seizure, and induction in rats treated with cycloheximide, indicates that verge is regulated as an immediate early gene in adult brain.

In situ analysis indicates that Verge mRNA is expressed in capillaries and in the cells lining the inner surface of veins and arteries (Fig. 3A-C), suggesting expression by endothelial cells. Verge mRNA was not detected in smooth muscle cells. Verge mRNA was also detected in the endocardium that lines the atria and ventricles of the heart (Fig. 3D). To confirm that verge $\mathrm{mRNA}$ is expressed in endothelial cells, dual fluorescent labeling was performed using the BS-1, which selectively binds endothelial cells (Thurston et al., 2000). Verge mRNA colocalized with BS-1 in isolated brain capillaries prepared from rats treated with cycloheximide (Fig. $3 E$ ). At high magnification, verge mRNA is visible in the perinuclear region, whereas the BS-1 lectin stains plasma membrane (Fig. $3 F$ ). Verge mRNA that is induced by cycloheximide was similarly detected in vessel endothelium of all tissues sampled (lung, liver, spleen, brain, retina, kidney, heart, adrenal gland, skin; data not shown).

Antibodies generated against $\mathrm{N}$ - and C-terminal peptides or GST fusion proteins detected Verge transgene expressed in COS cells. Verge Abs were specific and at least as sensitive as the best commercial anti-HA Abs in detecting the epitopetagged Verge transgene by Western blotting (Fig. $4 A$ ). However, native Verge protein was not clearly detected in lysates from hippocampus or other tissues of control rats. We next examined Verge protein expression in hippocampus of naive and kainate-treated rats. $\mathrm{N}$ - and C-terminal Verge antibodies recognized a kainateinducible protein of the correct molecular weight (Fig. $4 B$ ). Immunohistochemistry was performed using the same antibodies 

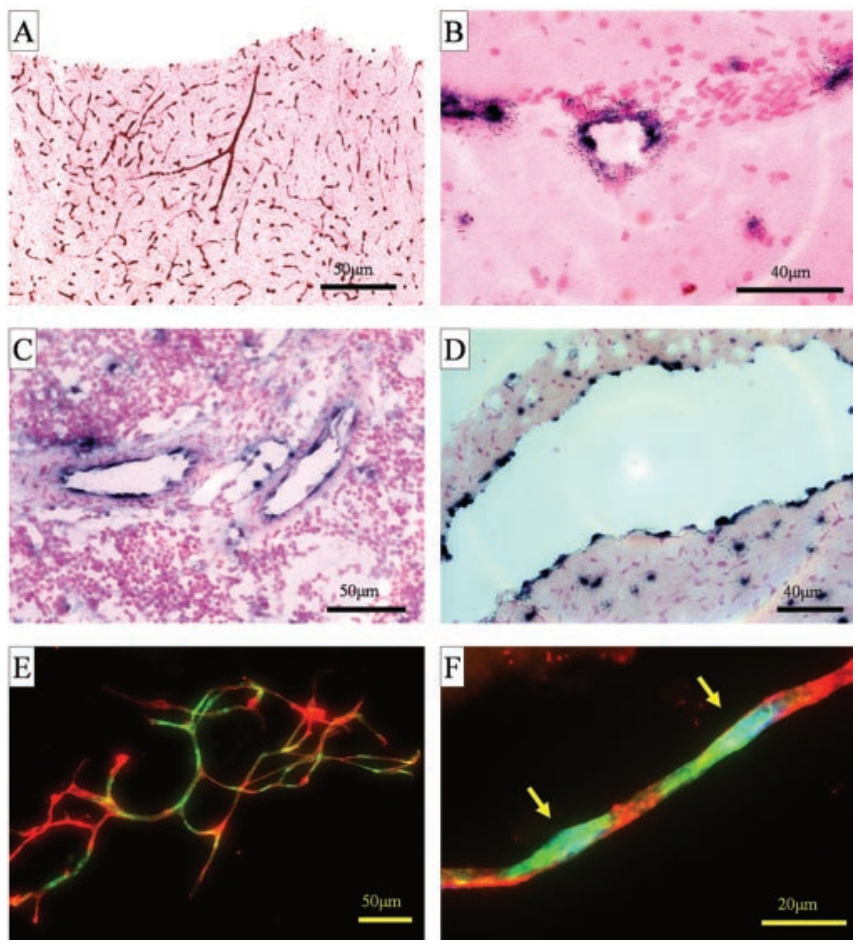

Figure 3. Verge is expressed in blood vessel endothelium. In situ hybridization analysis of verge $\mathrm{mRNA}$ in tissues from rats treated with cycloheximide ( $20 \mathrm{mg} / \mathrm{kg}$, i.p., for $2 \mathrm{hr}$ ). A, Verge mRNA in blood vessels in the cerebral cortex. $B-D$, High magnification of cerebral cortex $(B)$, spleen $(C)$, and heart ventricle $(D)$ showing verge in cells lining the intimal layers of blood vessels. Tissues are counterstained using nuclear fast red. $E$, $F$, Brain capillaries were isolated from rats treated with cycloheximide. Verge mRNA [detected by fluorescent in situ hybridization (FITC/green)] is expressed in cells that are costained by the endothelial cell marker lectin $B$. Simpliforica (Cy3-conjugated BS-1/red) (E). In F, nuclei are counterstained with DAPI (blue, arrows), and high magnification shows verge mRNA in the perinuclear region of cells staining for BS-1. Capillaries from control rats showed no verge mRNA signal (data not shown). Scale bars, $50 \mu \mathrm{m}$.

and revealed a specific signal in kainate-treated brain (Fig. $4 D, E$ ) that was not present in naive brain (Fig. 4C). Preimmune serum failed to detect a specific signal in kainate-treated brain (data not shown). Staining was restricted to small blood vessels, consistent with verge mRNA expression in endothelial cells. We conclude that Verge protein is induced by kainate seizures and is expressed in vascular cells in the adult brain.

\section{Verge is induced in cultured endothelial cells by TNF $\alpha$, FGF2,} and hypoxia

To investigate the effects of vascular bioactive molecules on verge expression, primary cultured mouse lung endothelial cells (MLECs) were exposed to either Ang-1 (50 ng/ml), Ang-2 (50 $\mathrm{ng} / \mathrm{ml})$, FGF2 (50 ng/ml), HGF (40 ng/ml), TNF- $\alpha$ (25 ng/ml), PMA (300 nM), or cycloheximide $(10 \mu \mathrm{g} / \mathrm{ml})$. Northern blot analysis was performed, and hybridization signals were quantified (Fig. 5A,B). Similar to in vivo studies, cycloheximide induced continuous verge mRNA expression. FGF2 and TNF- $\alpha$ each induced verge expression $\sim 20$-fold within 30 min after initial exposure. Verge mRNA levels returned to near baseline levels by $60 \mathrm{~min}$. HGF induced verge expression approximately twofold to threefold. PMA proved to be the most potent inducer of verge as mRNA levels increased 55-fold after 30 min of stimulation and were decreased at $60 \mathrm{~min}$. Ang- 1 and Ang- 2 showed subtle, if any, effects on verge expression at the concentrations and time points studied. Identical Northern blots were probed for $c$-fos, zif268, and jun $B$ mRNA, and their signal was quantified (Fig. 5B). Of these, $\mathrm{c}$-fos showed the most similar profile of responses suggesting a shared signaling pathway leading to transcriptional activation. Verge mRNA is also rapidly induced by FGF2 in primary mouse heart endothelial cells (Fig. 5C). These studies provide precedent in which verge can be induced in endothelial cells by membrane receptor signaling pathways.

We next examined verge mRNA expression in primary cultured human endothelial cells. Northern analysis confirmed that verge mRNA is expressed by neonatal HMVECs, and the $\sim 4.5$ $5.0 \mathrm{~kb}$ size corresponds well with estimated size of the human verge cDNA (4.6 kb) present in the NCBI database and ESTs identified by our laboratory (Fig. 5D). To investigate the effects of hypoxia on verge expression, HMVECs were exposed to hypoxic conditions. Verge mRNA expression revealed a time-dependent increase over the $3 \mathrm{hr}$ studied (Fig. 5D). Note that hypoxia and cycloheximide are the only stimuli identified to produce persistent upregulation of verge mRNA.

\section{Verge mRNA is focally induced by cerebral ischemia}

Based on the preceding observation that verge is differentially induced by defined growth factors or hypoxia, we examined the hypothesis that verge expression may be regulated by local conditions of the tissue. We examined the effect of focal ischemia on the expression of verge using a well characterized stroke model in which the middle cerebral artery of an adult mouse is transiently occluded by a filament that is threaded into the lumen of the vessel (Schneider et al., 1999). This model results in a transient disruption of the blood-brain barrier and increased vascular permeability (Cole et al., 1990; Betz et al., 1994). Transient focal ischemia ( $1.5 \mathrm{hr}$ ischemia and $2 \mathrm{hr}$ reperfusion) resulted in a threefold increase in verge mRNA expression in the ischemic hemisphere compared with the nonischemic hemisphere of the same animal (Fig. 6A). Similarly, immunofluorescence studies revealed increased Verge protein to be present in blood vessels in ischemic portions of brain (Fig. 6C), relative to nonischemic portions of the same brain (Fig. 6B). The increase in the ischemic hemisphere suggests that local tissue conditions can influence the induction or stability of verge mRNA and protein.

\section{Verge is developmentally regulated in the rat heart}

Although verge expression is low in normal adult vasculature, the abundance of verge ESTs from developing tissues suggested that it may be developmentally regulated. An initial survey of tissues from postnatal day (P) 0 rat confirmed prominent expression of verge $\mathrm{mRNA}$ in heart. Detailed in situ analysis of developing heart is presented in Figure 7. Verge mRNA is evident at high levels in heart from embryonic day (E) 17 to P12 (Fig. 7A-D). Verge expression is restricted to vessels. There is a marked decrease in verge expression between $\mathrm{P} 12$ (Fig. $7 D$ ) and $\mathrm{P} 17$ (Fig. $7 E$ ), and by $\mathrm{P} 30$ verge expression is no longer detected (Fig. $7 F$ ). The developmental progression of angiogenic activity is well documented in heart (Baldwin, 1996; Tomanek, 1996; Tomanek et al., 1996, 1999) and parallels the expression of verge.

\section{Verge protein is expressed in primary cultured endothelial} cells and localizes to focal regions at the periphery of the cell Using conventional approaches, we were not able to detect Verge protein in HMVECs under normoxic or hypoxic conditions by Western blotting. This stands in contrast to the striking induction of verge mRNA by hypoxia and growth factors (Fig. 5). IEG proteins are often in rapid turnover (Kruijer et al., 1984; Murphy et al., 2002), and treatment of cells with protease inhibitors can lead 


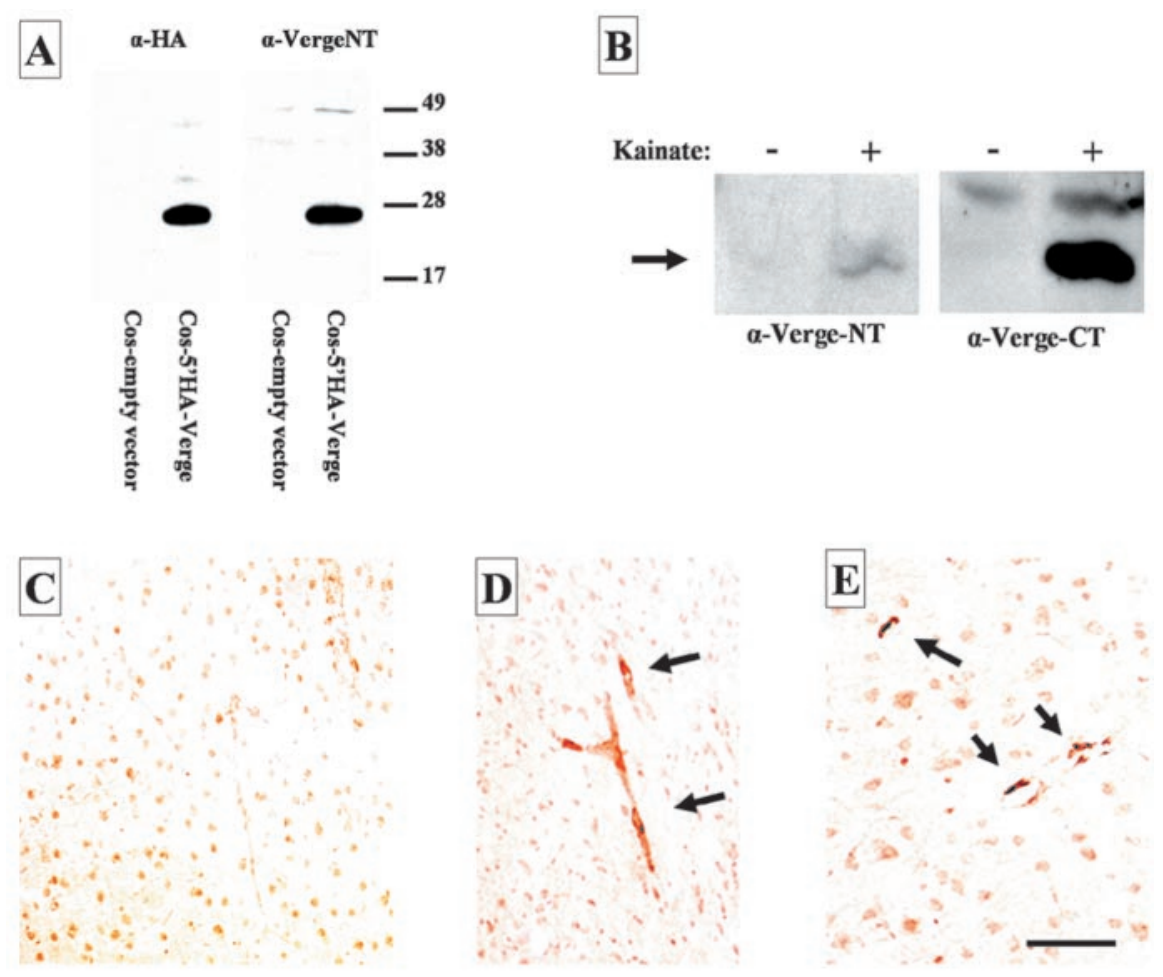

Figure 4. Kainic acid induces Verge protein in brain blood vessel endothelium. $A$, Western blot analysis of Verge protein expressed in transfected cells. COS cells were transiently transfected with either pRK5 empty vector or pRK5-5' HA-Verge. Anti-HA Ab confirms expression of HA-Verge protein (left panel) that is also detected with an Ab raised against an $\mathrm{N}$-terminal Verge peptide (right panel). B, Hippocampus from control and kainate-treated rats (kainic acid; $11 \mathrm{mg} / \mathrm{kg}$, i.p.; for $2 \mathrm{hr}$ ) was analyzed for Verge expression by Western blotting. Abs that generated against the $\mathrm{N}$ terminus and $\mathrm{C}$ terminus of Verge each detected an inducible protein of the correct molecular weight (arrow). $C-E$, Immunohistochemistry of Verge in hippocampus of rats treated with kainic acid as described in $B$. Immunoreactivity (anti-C-terminal $A b$ ) localizes to vessels (arrows) seen in longitudinal $(D)$ and transverse profiles $(E)$. No immunoreactivity was detected in control rat brain (C). Scale bar, $30 \mu \mathrm{m}$.

to accumulation of rapidly degraded proteins (Wang et al., 1994; Blagosklonny et al., 1999). Accordingly, we examined the effect of treating endothelial cells with protease inhibitors. Verge protein was detected in HMVEC lysates after treatment with the cysteine protease inhibitors ALLN and ALLM $(25 \mu \mathrm{g} / \mathrm{ml}$ of each added directly to media for 3-5 hr) (Fig. 8A). Western blots revealed a prominent band of $\sim 26 \mathrm{kDa}$ that was present in total lysates prepared from ALLN-ALLM-treated cells but not untreated cells. Immunofluorescence was performed to examine the subcellular localization of Verge in HMVECs. Staining with two independent Verge antibodies showed Verge protein to be enriched in cells treated with ALLN-ALLM and localized to the periphery of cells in close proximity to the plasma membrane (Fig. 8C,E). Verge immunoreactivity frequently showed focal accumulations along the periphery of cells. Peripheral staining was not seen in control HMVECs stained with preimmune serum (Fig. 8B,D) (data not shown). Confocal images confirmed that focal puncta of Verge localize to basolateral periphery, particularly at sites where the membrane displayed outward convexity (Fig. $8 F, G$ ). These data indicate that Verge protein is rapidly synthesized and degraded in HMVECs and suggest that Verge functions at or near the plasma membrane.

Stable Verge-expressing RBE4 cells show increased sensitivity to $\mathrm{PKC}$ stimulation in an in vitro assay of monolayer permeability

To examine the function of Verge in endothelial cells, we generated stable cell lines that express HA-tagged full-length Verge.
RBE4 cells, an immortalized cell line derived from rat brain microvasculature (Roux et al., 1994), were transfected with separate expression constructs for puromycin resistance and HA-tagged fulllength Verge. Although low levels of endogenous verge mRNA were detected in RBE 4 cells by RT-PCR, endogenous Verge protein was not detected in Western blots of total lysate (Fig. 9C, top panel). Four cell lines were selected and confirmed to express Verge transgene. In these cells, Verge transgene was evident in total lysates and migrated at the anticipated molecular mass. Two cell lines from the same screen that did not express Verge transgene were maintained as controls.

Because Verge accumulates at the periphery of HMVECs, we hypothesized that it might function to regulate endothelial cell barrier function. Accordingly, we performed assays of cellular permeability using Verge-expressing endothelial cell lines. Confluent monolayers of RBE4 clones were grown on gold electrodes in chambers designed to measure the electrical resistance of the layer using the method of Tiruppathi et al. (1992). Growth properties and measures of base line electrical resistance were identical for Vergeexpressing and nonexpressing (control) RBE4 cell lines (Table 1). We then examined the effect of adding agents that are reported to influence monolayer resistance. Thrombin and TGF- $\beta$ failed to affect permeability characteristics of either control or stable Vergeexpressing monolayers (Table 1). However, the PKC-activating phorbol ester PMA decreased monolayer resistance of stable Verge-expressing cells but not control cells (Table 1). In all four stably expressing Verge RBE4 clones, but not in two nonexpressing clones, PMA (100 nM) treatment induced a rapid decline in transendothelial electrical resistance (TER). A reduction of resistance was statistically significant within $10 \mathrm{~min}$, and $~ 90 \%$ of the response was complete by $30 \mathrm{~min}$ after agonist stimulation (Fig. $9 A$ ). The rapid kinetics and magnitude of PMA-induced increase in permeability is similar to that reported using primary endothelial cells (Verin et al., 2000). In contrast, cell lines that do not express Verge transgene showed $<10 \%$ reduction in monolayer resistance over the $3.5 \mathrm{hr}$ time course of the experiment. PMA effects were dose dependent and maximal at 100-300 nM (Fig. 9B).

We next examined the molecular mechanism of the PMA effect. Preincubation of 5'HA-Verge-expressing RBE4 cells with the PKC inhibitor BIM (Toullec et al., 1991) (1 $\mu \mathrm{M})$ did not alter basal electrical resistance but did block the PMA-induced decrease in electrical resistance (Table 2). Pretreatment with either U0126, a potent MAP kinase kinase (MEK) 1/2 inhibitor (Favata et al., 1998), or SB203580, which specifically inhibits p38 (Lee et al., 1994), did not affect basal resistance or responses to PMA (Table 2). We conclude that in this in vitro model of monolayer permeability, increased expression of Verge leads to an increased sensitivity to PMA that requires PKC. This effect does not appear to be dependent on MEK1/2 and p38. 
To further assess the mechanism of increased response to PMA, we performed Western blots on RBE4 cell lysates to assess expression of PKC isoforms that are reported to be expressed in endothelial cells and that are stimulated by PMA (Ferro et al., 2000; Idris et al., 2001; SiflingerBirnboim and Johnson, 2003). No significant change in expression levels of PKC- $\alpha$, $-\beta,-\gamma,-\delta$, or $-\epsilon$ were detected between Verge expressing and nonexpressing RBE4 cell lines (Fig. 9C). Thus, differences in response to PMA are not likely attributable to changes in expression of PKCs.

\section{PMA treatment of Verge-expressing} RBE4 cells leads to a rapid and transient remodeling of the actin cytoskeleton and the formation of paracellular gaps PMA-induced increases in endothelial cell permeability are often associated with changes in cell shape, reorganization of the cytoskeleton, and the formation of paracellular gaps (Antonov et al., 1986; Grigorian and Ryan, 1987; Lynch et al., 1990; Garcia et al., 1992). As noted, control and Verge-expressing RBE4 cell lines form similar monolayers, and staining of nuclei confirm their cell density to be approximately equal (Fig. 10A,B). Visualization of F-actin with FITC-labeled phalloidin showed that the actin stress fiber network is also similar in control and Vergeexpressing RBE4 cells (Fig. 10C,D, respectively). In Verge-expressing RBE4 cells, treatment with PMA (100 nM, 1 hr) led to a reorganization of the actin cytoskeleton and the formation of paracellular gaps (Fig. 10F). PMA failed to induce a change in actin cytostructure or formation of paracellular gaps in the control, nonVerge-expressing lines (Fig. 10 E). Remodeling of the actin cytoskeleton and the formation of paracellular gaps was transient as normal monolayer morphology returned to stable expressing cell lines $24 \mathrm{hr}$ after continuous PMA treatment (data not shown).

\section{Discussion}

We describe the cloning and initial characterization of a novel gene that is selectively expressed in vascular endothelium. In the adult brain, verge mRNA is rapidly and transiently induced by a number of stimuli including the protein synthesis inhibitor cycloheximide. These observations indicate that verge is regulated as an IEG. In contrast to adult endothelium, where expression in normal tissue is very low, verge is prominently expressed during developmental angiogenesis. Verge ESTs are also present in many human tumor libraries from brain and other tissues, suggesting it contributes broadly to vascular biology.

Verge encodes a 73 amino acid region that is $30 \%$ identical to the ApoL family of proteins. It is unlikely that Verge represents control for RNA loading.
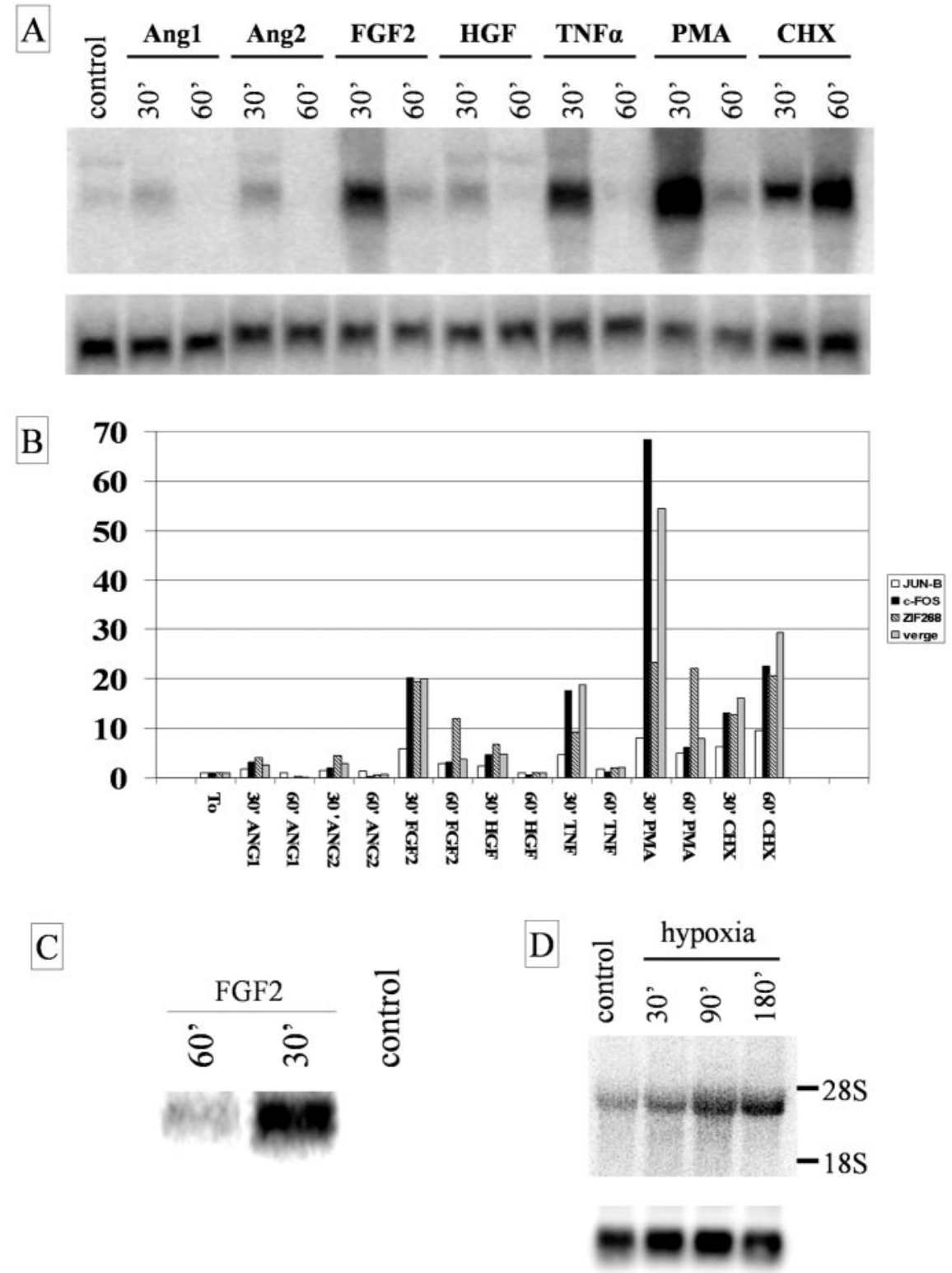

Figure 5. Analysis of Verge expression in primary endothelial cells, regulation by various bioactive molecules, and hypoxia. $A$, A study of verge $m R N A$ expression in primary cultured MLECs. Total RNA was isolated at the indicated time points after cells were stimulated with Ang-1 $(50 \mathrm{ng} / \mathrm{ml})$, Ang-2 (50 ng/ml), FGF2 (50 ng/ml), HGF (40 ng/ml), TNF- $\alpha(25 \mathrm{ng} / \mathrm{ml})$, PMA (300 nM), or cycloheximide $(10 \mu \mathrm{g} / \mathrm{ml})$ and analyzed by Northern blotting. FGF2, TNF $\alpha$, PMA, and cycloheximide potently induce verge expression. Lower blot shows GAPDH as a control for RNA loading. B, Quantification of mRNA induction of verge (gray), jun-B (white), c-fos (black), and zif 268 (black and white stripes) in MLECS. C, FGF2 can also induce verge mRNA in primary mouse cardiac endothelial cells. D, Human microvascular endothelial cells (HMVECS) were placed in a hypoxic chamber. At indicated time points total RNA was isolated from cells and verge mRNA expression was analyzed by Northern blot analysis. The $\$ 26$ gene was used as a

another ApoL family member because Verge shows no homology to other regions of the ApoLs, whereas known family members show significant homology throughout. Also, the ApoL family most likely arose from a series of gene duplications in a $619 \mathrm{~kb}$ region on human chromosome 22 (Page et al., 2001), whereas human verge is present on chromosome 12. Although ApoL-1 has been shown to be secreted and present in high-density lipoprotein fractions (Duchateau et al., 1997), no functional data are currently known regarding the ApoL proteins. The same region of Verge shows 30 and 25\% identity to hypothetical Fugu rubripes and C. elegans proteins, respectively. The presence of a conserved 

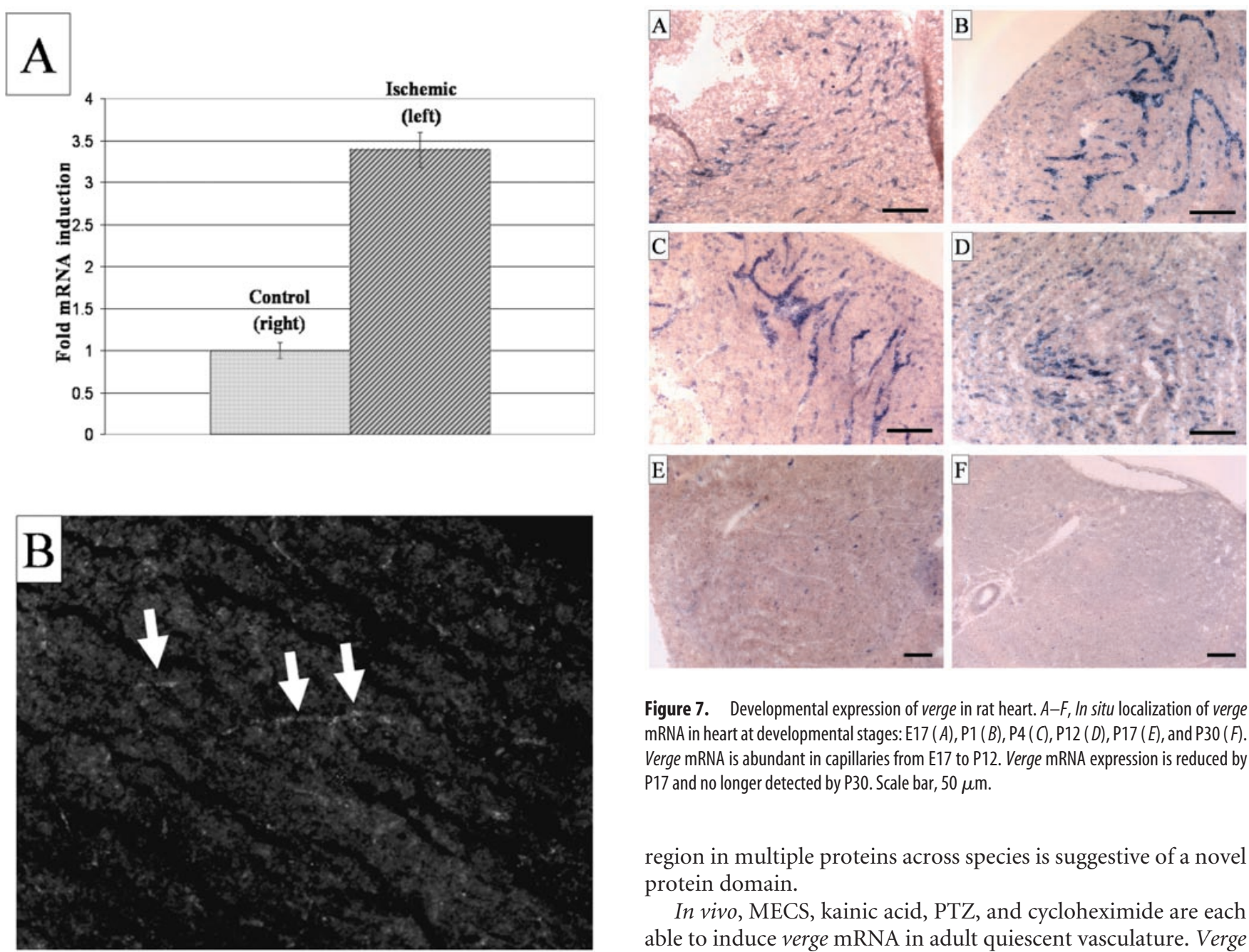

Figure 7. Developmental expression of verge in rat heart. $A-F$, In situ localization of verge mRNA in heart at developmental stages: $\mathrm{E} 17(A), \mathrm{P} 1(B), \mathrm{P} 4(C), \mathrm{P} 12(D), \mathrm{P} 17(E)$, and $\mathrm{P} 30(F)$. Verge $\mathrm{mRNA}$ is abundant in capillaries from E17 to $\mathrm{P} 12$. Verge $\mathrm{mRNA}$ expression is reduced by $\mathrm{P} 17$ and no longer detected by P30. Scale bar, $50 \mu \mathrm{m}$.

region in multiple proteins across species is suggestive of a novel protein domain.

In vivo, MECS, kainic acid, PTZ, and cycloheximide are each able to induce verge mRNA in adult quiescent vasculature. Verge mRNA induction by cycloheximide is rapid and robust and comparable with c-fos. The ability of cycloheximide to superinduce IEGs appears to result from inhibition of transcription repressors

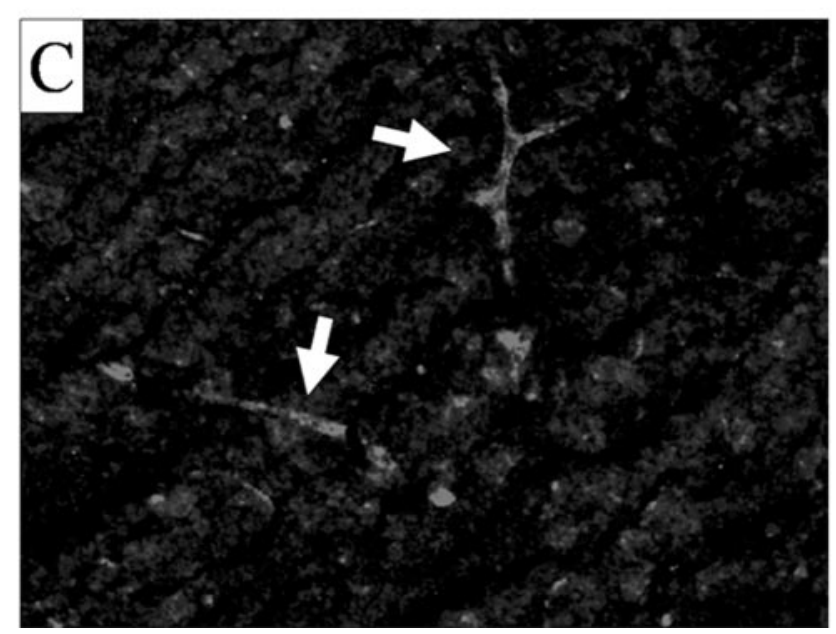

Figure 6. Verge mRNA and protein is induced in an animal model of focal ischemia. Quantitative RT-PCR was performed to assess induction of verge mRNA in mouse brain. A, MCA occlusion model of cerebral ischemia ( $1.5 \mathrm{hr}$ ischemia and $2 \mathrm{hr}$ reperfusion) shows a more than threefold induction $(3.39 \pm 0.21 ; n=4)$ of verge $\mathrm{mRNA}$ in the ischemic hemisphere compared with the control hemisphere. $B, C$, Immunofluorescence with anti-Verge Ab revealed increased expression of Verge protein in cortical blood vessels (arrows) in the ischemic portion of the brain (C) compared with normoxic portions of the same brain $(B)$. that are normally rapidly induced (Greenberg et al., 1986; Lau and Nathans, 1991; Nathans et al., 1991). Ang-1 and Ang-2 showed little significant induction of verge mRNA in cultured endothelial cells. In contrast, FGF2, TNF- $\alpha$, PMA, hypoxia, and cycloheximide proved to be rapid, potent inducers. Of the known signaling pathways that are activated by these stimuli, nuclear factor- $\kappa \mathrm{B}$ and stress-activated protein kinase/c-Jun N-terminal kinase appear to be shared and therefore are candidate signaling pathways responsible for verge induction. Independent of the precise mechanism, it is evident that new protein synthesis is not required for verge mRNA induction. As hypoxia, FGF2 and TNF $\alpha$ signaling are important in angiogenesis and inflammation, our studies suggest that Verge could contribute to these biological responses.

Verge is notable in that it is the only gene identified in our screen for seizure-induced cDNAs in adult brain that is expressed selectively in vascular endothelium. We and others reported $\sim 20$ IEGs that are induced by seizure in neurons (Sheng and Greenberg, 1990; Nedivi et al., 1993; Lanahan and Worley, 1998; Walton et al., 1999; Herschman et al., 2000). Certain IEGs can also be expressed in endothelial cells (Fig. 5), but Verge is present only in endothelial cells and is not expressed or induced in neurons in vivo. Interestingly, neural activity is known to result in rapid growth of capillaries in brain and is age dependent (Black et al., 1987; Churchill et al., 2002). Because Verge is induced by sei- 
A
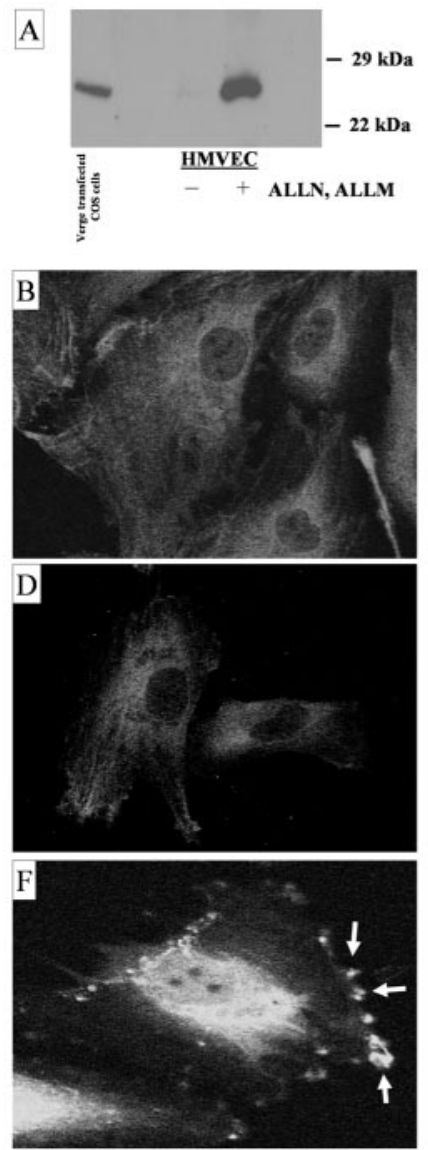
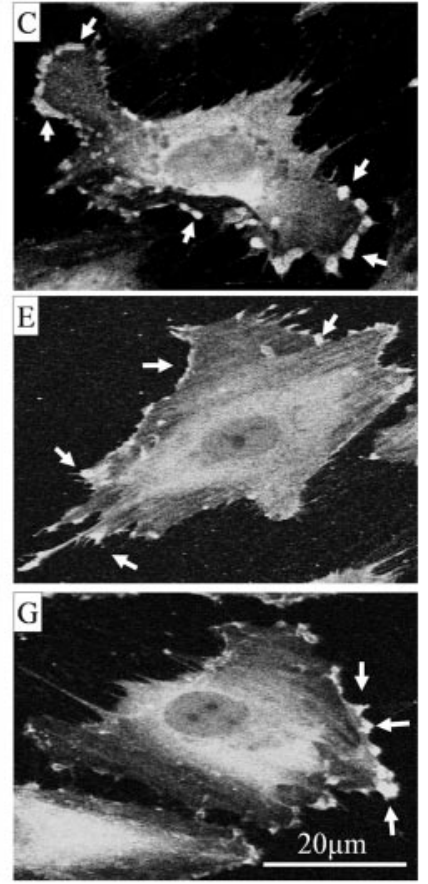

Figure 8. Analysis of Verge expression in primary endothelial cells, regulation, and focal accumulation of verge protein at the cell periphery. $A$, Western blot analysis (using Ab 25 generated against human Verge residues 39 -52) reveals accumulation of Verge protein after treatment of HMVECs with the cysteine protease inhibitors ALLN and ALLM ( $25 \mu \mathrm{g} / \mathrm{ml}, 3 \mathrm{hr}$ ). Lysate from $C O S-1$ cells transiently transfected with Verge was used as a positive control ( $A$, left lane). $B-G$, Subcellular localization of Verge in HMVECs. Ab 25 shows focal staining at the periphery of ALLN/ALLM-treated cells ( $C$, arrows), preimmune control for Ab 25 ( $B$ ). Likewise, Ab 30 (generated against Verge residues 3-21) also recognizes specific puncta present at the periphery of inhibitor-treated cells ( $E$, arrows), preimmune control for $A b 30$ (D). F, G, $1 \mu \mathrm{m}$ confocal sections show Verge puncta ( $\mathrm{Ab} 30$ ) are enriched and nearly confluent at prominences along a basolateral surface of the cell $(G)$ but are discrete at more apical regions of the cell ( $F$, arrows).

zures, which result in increased neuronal activity, and can be induced by soluble factors such as FGF2 and TNF $\alpha$, which are produced by both neurons and glia (Woodward et al., 1992; Allan and Rothwell, 2001), it is possible that verge plays a role in activity-dependent changes of brain vasculature. Enhanced expression ipsilateral to middle cerebral artery (MCA) occlusion in the stroke model supports the notion that verge can respond to local conditions within the tissue. Whether the critical stimulus in this model is hypoxia- or tissue-derived signaling molecules remains to be determined.

Verge protein also appears to be under tight regulation because inhibition of cysteine proteases results in its rapid accumulation. There is ample precedent for rapid degradation of IEGs. For example, c-fos is rapidly translated and degraded unless phosphorylated by ERK (extracellular signal-regulated kinase), which leads to stabilization of c-fos protein (Murphy et al., 2002). It is inferred that the absolute level and temporal dynamics of IEG protein is critical for cellular function.

Studies of Verge-expressing brain endothelial cells suggest

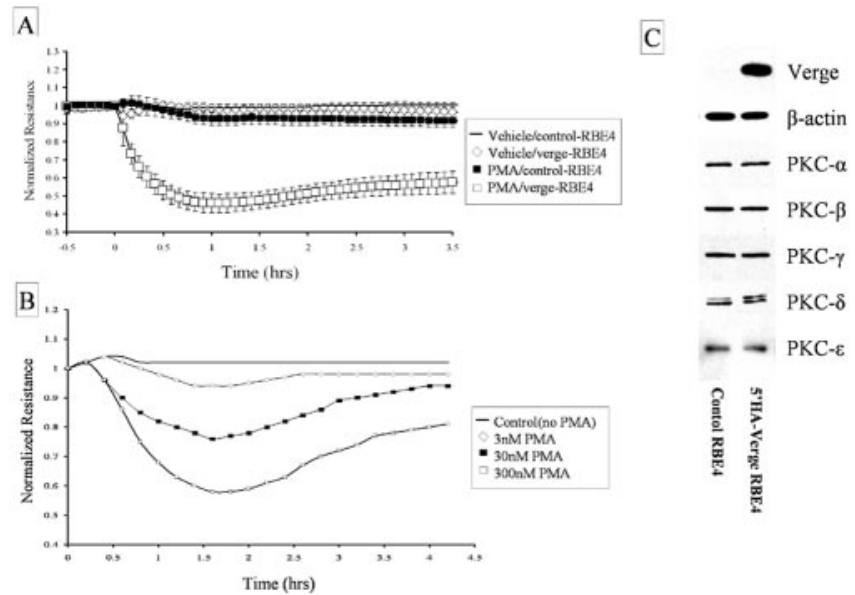

Figure 9. Stable Verge-expressing RBE4 cells show increased sensitivity to PMA in an in vitro assay of endothelial cell monolayer permeability. $A$, The effect of PMA on TER in control and 5'HA-Verge-expressing RBE4 cells was assessed. Shown are measurements of normalized electrical resistance across a monolayer of endothelial cells grown to confluence on ECIS gold microelectrode plates. Each experiment represents the pooled TER values of two independent control (clones A and B) and two independent stable Verge-expressing (clones 38 and 41) cell lines examined in three independent experiments $(n=3)$. Endothelial cells were rinsed with DMEM to remove serum, incubated to stabilize basal electrical resistance, and then treated with either vehicle $(0.1 \%$ DMSO) or PMA ( $100 \mathrm{~nm})$. Data are expressed as mean TER \pm SD versus time. Verge-expressing RBE4 cells are responsive to PMA, but control cells are not. $B$, A representative experiment showing dose responsiveness of Verge-expressing RBE4 cells to PMA. Cells were treated with vehicle (0.1\% DMSO), $3 \mathrm{~nm}$ PMA, $30 \mathrm{~nm}$ PMA, or $300 \mathrm{~nm}$ PMA, and TER was measured over $4.5 \mathrm{hr}$. C, Analysis of PKC isoform expression in control (clone A) and Vergeexpressing RBE4 cells (clone 38). PKC isoform expression was not altered in Verge-expressing cell lines. Similar comparisons of both control and all four Verge-expressing cell lines failed to detect changes in PKC expression (data not shown).

that Verge modifies the response to activation of protein kinase C. In these cells, PMA induces an increase in monolayer permeability that is accompanied by a rapid, time-dependent remodeling of the actin cytoskeleton and formation of paracellular gaps. This type of response is seen in numerous primary endothelial cells in culture but is absent in the parental RBE4 cell line. Accordingly, Verge appears to restore PKC-dependent pathways that regulate cell shape and cell-cell contact to RBE4 cells. Verin et al. (2000) observed a similar PMA-dependent phenomenon in cultured pulmonary endothelial cells and described the following signaling pathway. PMA activation results in PKC- $\alpha$ translocation to the plasma membrane and leads to the sequential activation of Ras, Raf-1, MEK-1/2, and ERK1/2. However, inhibition of MEK $1 / 2$ blocked only $30-50 \%$ of the PMA effect, suggesting a role for a second PKC-dependent, MEK1/2-independent pathway that leads to increased monolayer permeability. This pathway is consistent with effects of Verge expression in brain endothelial cells and deserves additional scrutiny. It is also worth noting that PMA is a potent inducer of verge expression in lung endothelial cells and suggests the potential of a feedback loop in which an initial PKC stimulation leads to verge upregulation and may affect future PKC signaling events.

Our studies also support the notion that Verge induction by one stimulus could alter the signaling properties of endothelial cells to a subsequent stimulus in a way that enhances PKC signaling. Verge would thus provide a molecular mechanism for crosstalk between signaling pathways. PKC signaling is implicated in modulating barrier function both in endothelial cells containing tight junctions (Lippoldt et al., 2000; Sukumaran and Prasadarao, 2003), like those making up the blood-brain barrier, as well as 
Table 1. Analysis of control and stable Verge-expressing RBE4 cells: effect of different endothelial cell agonists on barrier function

\begin{tabular}{|c|c|c|c|c|c|c|c|c|c|c|c|}
\hline \multicolumn{6}{|c|}{ Non-5'HA-Verge-expressing cells } & \multicolumn{6}{|c|}{ 5'HA-Verge-expressing cells } \\
\hline Thrombin & & TGF- $\beta$ & & PMA & & Thrombin & & TGF- $\beta$ & & PMA & \\
\hline- & + & - & + & - & + & - & + & - & + & - & + \\
\hline $1.012 \pm 0.02$ & $0.973 \pm 0.12$ & $1.004 \pm 0.03$ & $0.947 \pm 0.05$ & $1.007 \pm 0.03$ & $0.960 \pm 0.09$ & $1.009 \pm 0.03$ & $0.977 \pm 0.13$ & $1.001 \pm 0.03$ & $0.952 \pm 0.06$ & $1.010 \pm 0.02$ & $0.563 \pm 0.13^{* *}$ \\
\hline
\end{tabular}

Normalized TER values are means \pm SD in $\Omega$. Each experiment represents the pooled TER values of two independent control (clones $A$ and $B$ ) and two independent stable Verge-expressing (clones 38 and 41 ) cell lines ( $n=3$ ). RBE4 cells were grown to confluence on ECIS plates, and cells were rinsed with DMEM to remove serum and incubated in fresh DMEM for 30 min to achieve stable basal electrical resistance. Cells were then treated with vehicle, thrombin (100 $\mathrm{nm}$, 15 $\min )$, TGF- $\beta(1 \mathrm{ng} / \mathrm{ml}, 20 \mathrm{hr})$, or PMA (100 nm, $1 \mathrm{hr})$. PMA treatment resulted in reduced electrical resistance in mutant cell clones. ${ }^{* *} p<0.05$ between control and PMA-treated groups.

Table 2. Analysis of control and stable Verge-expressing RBE4 cells: monolayer permeability and sensitivity to kinase inhibitors

\begin{tabular}{|c|c|c|c|c|c|c|c|c|}
\hline \multirow[b]{2}{*}{ Treatment } & \multicolumn{4}{|c|}{ Non-5'HA-Verge-expressing cells } & \multicolumn{4}{|c|}{$5^{\prime}$ HA-Verge-expressing cells } \\
\hline & Control & U0126 & SB & BIM & Control & U0126 & SB & BIM \\
\hline Vehicle & $0.998 \pm 0.03$ & $0.998 \pm 0.05$ & $0.903 \pm 0.05$ & $0.973 \pm 0.06$ & $1.003 \pm 0.02$ & $0.996 \pm 0.07$ & $0.910 \pm 0.07$ & $0.980 \pm 0.08$ \\
\hline PMA & $0.940 \pm 0.08$ & $0.927 \pm 0.06$ & $0.960 \pm 0.08$ & $0.880 \pm 0.08$ & $0.561 \pm 0.12^{* *}$ & $0.631 \pm 0.07^{* *}$ & $0.551 \pm 0.10^{* *}$ & $0.860 \pm 0.08$ \\
\hline
\end{tabular}

Normalized TER values are means \pm SD in $\Omega$. Each experiment represents the pooled TER values of two independent control (clones $A$ and B) and two independent stable Verge-expressing (clones 38 and 41 ) cell lines ( $n=3$ ). RBE 4 cells were grown to confluence on ECIS plates, and cells were rinsed with DMEM to remove serum and incubated in fresh DMEM for 30 min to achieve stable basal electrical resistance. Cells were then treated with vehicle, U0126 (10 $\mu \mathrm{M}$ ), SB203580 $(10 \mu \mathrm{M})$, or BIM $(1 \mu \mathrm{M})$ for $30 \mathrm{~min}$ followed by PMA (100 nM) for $1 \mathrm{hr}$. Stimulation of Verge-expressing cells, but not control cells, with PMA leads to a significant decrease in TER. Pretreatment of Verge-expressing cells with BIM blocks the PMA-induced increase in permeability. Pretreatment with either U0126 or SB203580 produced no effect $\left.{ }^{* *} p<0.05\right)$.
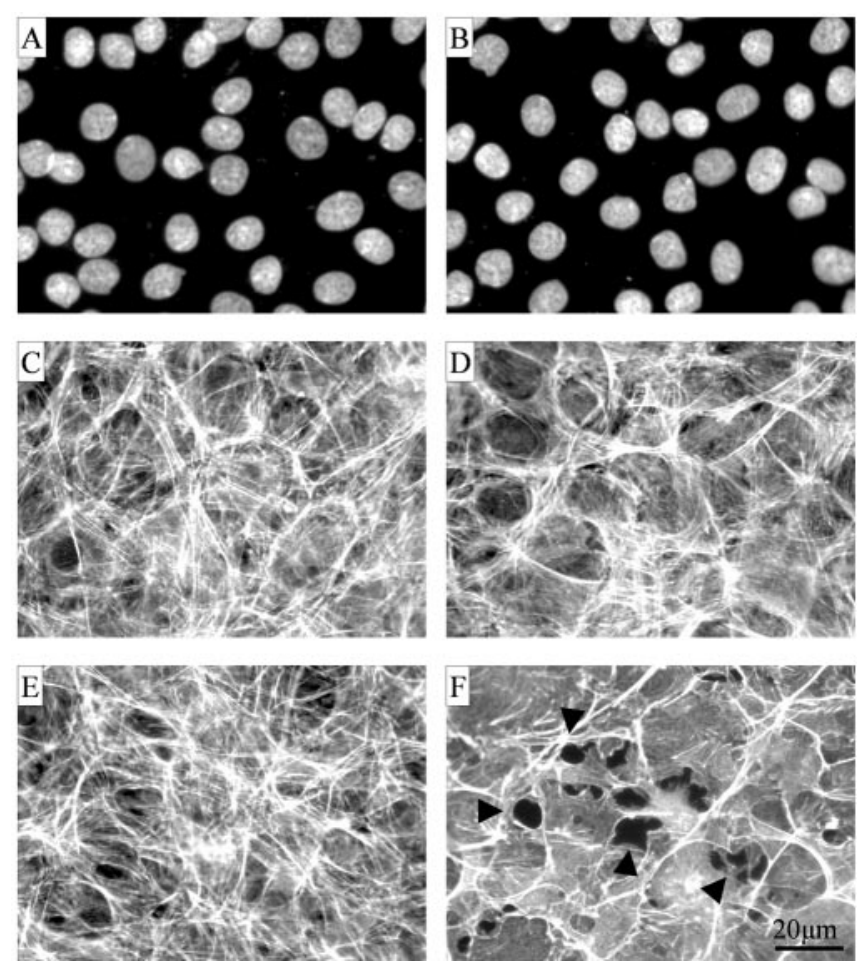

Figure 10. Treatment of Verge-expressing RBE4 cells with PMA causes remodeling of the actin cytoskeleton and the formation of paracellular gaps. $A, B$, DAPI staining of control (clone $A$; $A$ ) and Verge-expressing RBE4 cells (clone 38; $B$ ) grown to confluence on glass coverslips shows equal cell densities within the monolayer. $C, D$, Treatment of control $(C)$ and stable Vergeexpressing (D) RBE4 cells with vehicle ( $0.1 \%$ DMSO) for $1 \mathrm{hr}$ showed no effect on endothelial actin cytostructure (as visualized using FITC-labeled phalloidin). F, PMA treatment (100 nM, $1 \mathrm{hr}$ ) of stable Verge-expressing cells showed alterations in the actin cytoskeleton leading to the formation of paracellular gaps (arrowheads). E, PMA treatment of control cells produced no obvious effect on actin cytoskeleton and no formation of paracellular gaps.

those without tight junctions. PKC is a common downstream signaling pathway important in response to a number of endothelial cell permeability-inducing agents, including vascular endothelial growth factor (VEGF) (Wu et al., 1999; Breslin et al., 2003), thrombin (Lynch et al., 1990), TNF $\alpha$ (Ferro et al., 2000), bradykinin (Murray et al., 1991; Shigematsu et al., 2002), plateletactivating factor (Kobayashi et al., 1994), and reactive oxygen species (Zhao and Davis, 1998). PKC functioning downstream of
VEGF activation has been shown to play a key role in both the mitogenic and permeability-inducing activities of VEGF (Wu et al., 1999). Cellular mechanisms by which PKCs are thought to lead to increased permeability include phosphorylation of cytoskeletal proteins (Stasek et al., 1992; Yuan, 2002), disassembly of VE-cadherin junctions (Sandoval et al., 2001; Sukumaran and Prasadarao, 2003), prostaglandin synthesis (Garcia et al., 1992; Saishin et al., 2003), and nitric oxide synthesis (Ramirez et al., 1996; Huang and Yuan, 1997). PKC-dependent signaling events within endothelial cells that lead to increased permeability and barrier dysfunction have been implicated in a number of human diseases, including sepsis, acute lung injury, ARDS, and diabetes (Bannerman and Goldblum, 1999; Idris et al., 2001; SiflingerBirnboim and Johnson, 2003). Electrical or chemical seizure and focal ischemia, which induce verge, also lead to increased vascular permeability (Lorenzo et al., 1972; Sperk et al., 1983). Although the data presented in this study lays the groundwork describing a novel protein involved in modulating vascular permeability, it is important to note that the model used to study verge function thus far is an immortalized brain endothelial cell line and thus may not fully replicate the function of verge in vivo. Determining the stimuli that lead to verge expression and the PKC-dependent mechanisms by which verge expression may affect blood-brain permeability in vitro and in vivo will require additional experimentation. Nonetheless, it is intriguing to speculate that Verge plays a role in modulating both angiogenesis and barrier function.

\section{References}

Allan SM, Rothwell NJ (2001) Cytokines and acute neurodegeneration. Nat Rev Neurosci 2:734-744.

Allport JR, Lim YC, Shipley JM, Senior RM, Shapiro SD, Matsuyoshi N, Vestwever D, Luscinskas FW (2002) Neutrophils from MMP-9-and neutrophil elastase-deficient mice show no defect in transendothelial migration under flow in vitro. J Leukoc Biol 71:821-828.

Antonov AS, Lukashev ME, Romanov YA, Tkachuk VA, Repin VS, Smirnov VN (1986) Morphological alterations in endothelial cells from human aorta and umbilical vein induced by forskolin and phorbol 12-myristate 13-acetate: a synergistic action of adenylate cyclase and protein kinase C activators. Proc Natl Acad Sci USA 83:9704-9708.

Baldwin HS (1996) Early embryonic vascular development. Cardiovasc Res 31:E34-E45.

Bannerman DD, Goldblum SE (1999) Direct effects of endotoxin on the endothelium: barrier function and injury. Lab Invest 79:1181-1199.

Bernard GR, Artigas A, Brigham KL, Carlet J, Falke K, Hudson L, Lamy M, Legall JR, Morris A, Spragg R (1994) The Am-Eur consensus conference 
on ARDS. Definitions, mechanisms, relevant outcomes, and clinical trial coordination. Am J Respir Crit Care Med 149:818-824.

Betz AL, Keep RF, Beer ME, Ren XD (1994) Blood-brain barrier permeability and brain concentration of sodium, potassium, and chloride during focal ischemia. J Cereb Blood Flow Metab 14:29-37.

Black JE, Sirevaag AM, Greenough WT (1987) Complex experience promotes capillary formation in young rat visual cortex. Neurosci Lett 83:351-355.

Blackshaw S, Snyder SH (1997) Developmental expression pattern of phototransduction components in mammalian pineal implies a light-sensing function. J Neurosci 17:8074-8082.

Blagosklonny MV, An WG, Melillo G, Nguyen P, Trepel JB, Neckers LM (1999) Regulation of BRCA1 by protein degradation. Oncogene 18:6460-6468.

Brambrink AM, Schneider A, Noga H, Astheimer A, Gotz B, Korner I, Heimann A, Welschof M, Kempski O (2000) Tolerance-Inducing dose of 3-nitropropionic acid modulates bcl-2 and bax balance in the rat brain: a potential mechanism of chemical preconditioning. J Cereb Blood Flow Metab 20:1425-1436.

Breslin JW, Pappas PJ, Cerveira JJ, Hobson Jr RW, Duran WN (2003) VEGF increases endothelial permeability by separate signaling pathways involving ERK-1/2 and nitric oxide. Am J Physiol Heart Circ Physiol 284:H92-H100.

Churchill JD, Galvez R, Colcombe S, Swain RA, Kramer AF, Greenough WT (2002) Exercise, experience and the aging brain. Neurobiol Aging 23:941-955.

Cole DJ, Drummond JC, Matsumura JS, Marcantonio S, Chi-Lum BI (1990) Hypervolemic-hemodilution and hypertension during temporary middle cerebral artery occlusion in rats: the effect on blood-brain barrier permeability. Can J Neurol Sci 17:372-377.

Duchateau PN, Pullinger CR, Orellana RE, Kunitake O, Naya-Vigne J, O'Connor PM, Malloy MJ, Kane JP (1997) Apolipoprotein L, a new human high density lipoprotein apolipoprotein expressed by the pancreas. Identification, cloning, characterization, and plasma distribution of apolipoprotein L. J Biol Chem 272:25576-25582.

Dudek SM, Garcia JG (2001) Cytoskeletal regulation of pulmonary vascular permeability. J Appl Physiol 91:1487-1500.

Favata MF, Horiuchi KY, Manos EJ, Daulerio AJ, Stradley DA, Feeser WS, Van Dyk DE, Pitts WJ, Earl RA, Hobbs F, Copeland RA, Magolda RL, Scherle PA, Trzaskos JM (1998) Identification of a novel inhibitor of mitogen-activated protein kinase kinase. J Biol Chem 273:18623-18632.

Ferro T, Neumann P, Gertzberg N, Clements R, Johnson A (2000) Protein kinase C-alpha mediates endothelial barrier dysfunction induced by TNF-alpha. Am J Physiol Lung Cell Mol Physiol 278:L1107-L1117.

Garcia JG, Liu F, Verin AD, Birukova V, Dechert MA, Gerthoffer WT, Bamberg JR, English D (2001) Sphingosine 1-phosphate promotes endothelial cell barrier integrity by Edg-dependent cytoskeletal rearrangement. J Clin Invest 108:689-701.

Garcia JG, Stasek J, Natarajan V, Patterson CE, Dominguez J (1992) Role of protein kinase $\mathrm{C}$ in the regulation of prostaglandin synthesis in human endothelium. Am J Respir Cell Mol Biol 6:315-325.

Goldstein GW, Wolinsky JS, Csejtey J, Diamond I (1975) Isolation of metabolically active capillaries from rat brain. J Neurochem 25:715-717.

Greenberg ME, Hermanowski AL, Ziff EB (1986) Effect of protein synthesis inhibitors on growth factor activation of c-fos, c-myc, and actin gene transcription. Mol Cell Biol 6:1050-1057.

Grigorian GY, Ryan US (1987) Platelet-activating factor effects on bovine pulmonary artery endothelial cells. Circ Res 61:389-395.

Herschman HR, Ferguson GD, Feldman JD, Farias-Eisner R, Vician L (2000) Searching for depolarization-induced genes that modulate synaptic plasticity and neurotrophin-induced genes that mediate neuronal differentiation. Neurochem Res 25:591-602.

Huang Q, Yuan Y (1997) Interaction of PKC and NOS in signal transduction of microvascular hyperpermeability. Am J Physiol 273:H2442-H2451.

Idris I, Gray S, Donnelly R (2001) Protein kinase C activation: isozymespecific effects on metabolism and cardiovascular complications in diabetes. Diabetologia 44:659-673.

Klagsbrun M (1996) Blood vessels. Scientific Am 1:63-78.

Kobayashi I, Kim D, Hobson Jr RW, Duran WN (1994) Platelet-activating factor modulates microvascular transport by stimulation of protein kinase C. Am J Physiol 266:H1214-H1220.

Kozak M (1981) Possible role of flanking nucleotides in recognition of the
AUG initiator codon by eukaryotic ribosomes. Nucleic Acids Res 9:5233-5262.

Kruijer W, Cooper JA, Hunter T, Verma IM (1984) Platelet-derived growth factor induces rapid but transient expression of the c-fos gene and protein. Nature 312:711-716.

Kyte J, Doolittle RF (1982) A simple method for displaying the hydropathic character of a protein. J Mol Biol 157:105-132.

Lanahan A, Worley PF (1998) Immediate-early genes and synaptic function. Neurobiol Learn Mem 70:37-43.

Lau LF, Nathans D (1991) Genes induced by serum growth factors. In: The hormonal control of gene transcription (Cohen P, Foulkes J, eds), pp 257-293. Amersterdam: Elsevier.

Lee JC, Laydon JT, McDonnell PC, Gallagher TF, Kumar S, Green D, McNulty D, Blumenthal MJ, Heys JR, Landvatter SW, Strickler JE, McLaughlin MM, Siemens IR, Fisher SM, Livi GP, White JR, Adams JL, Young PR (1994) A protein kinase involved in the regulation of inflammatory cytokine biosynthesis. Nature 372:739-746.

Lippoldt A, Liebner S, Andbjer B, Kalbacher H, Wolburg H, Haller H, Fuxe K (2000) Organization of choroid plexus epithelial and endothelial cell tight junctions and regulation of claudin-1, -2 and -5 expression by protein kinase C. NeuroReport 11:1427-1431.

Lorenzo AV, Shirahige I, Liang M, Barlow CF (1972) Temporary alteration of cerebrovascular permeability to plasma protein during drug-induced seizures. Am J Physiol 223:268-277.

Lum H, Malik AB (1996) Mechanisms of increased endothelial permeability. Can J Physiol Pharmacol 74:787-800.

Lupas A, Van Dyke M, Stock J (1991) Predicting coiled coils from protein sequences. Science 252:1162-1164.

Lynch JJ, Ferro TJ, Blumenstock FA, Brockenauer AM, Malik AB (1990) Increased endothelial albumin permeability mediated by protein kinase $\mathrm{C}$ activation. J Clin Invest 85:1991-1998.

Majesky M (2001) Development of the vascular system. In: Hemostasis and thrombosis: basic principles and clinical practice (Colman RW, Hirsch J, Marder VJ, Clowes AW, George JN, eds), pp 597-613. Philadelphia: Lippincott, Williams and Wilkins.

Majno G, Palade G (1961) Studies on inflammation. 1. Effect of histamine and serotinin on vascular permeability: an electron microscopic study. J Biophys Biochem Cytol 11:571-605.

Majno G, Shea S, Leventhal M (1969) Endothelial contraction induced by histamine type mediators: an electron microscopic study. J Cell Biol 42:647-672.

McDonald DM, Thurston G, Baluk P (1999) Endothelial gaps as sites for plasma leakage in inflammation. Microcirculation 6:7-22.

Minshall RD, Tiruppathi C, Vogel SM, Malik AB (2002) Vesicle formation and trafficking in endothelial cells and regulation of endothelial barrier function. Histochem Cell Biol 117:105-112.

Murphy LO, Smith S, Chen RH, Fingar DC, Blenis J (2002) Molecular interpretation of ERK signal duration by immediate early gene products. Nat Cell Biol 4:556-564.

Murray MA, Heistad DD, Mayhan WG (1991) Role of protein kinase C in bradykinin-induced increases in microvascular permeability. Circ Res 68:1340-1348.

Nathans D, Christy BA, Dubois R, Lanahan AA, Sanders LK, Nakabeppu Y (1991) Transcription factors induced by growth-signalling agents. In: Origins of human cancer: a comprehensive review (Brugge J, Curran T, Harlow E, McCormick F, eds), pp 353-364. Plainview, NY: Cold Spring Harbor Laboratory.

Nedivi E, Hevroni D, Naot D, Israeli D, Citri Y (1993) Numerous candidate plasticity-related genes revealed by differential cDNA cloning. Nature 363:718-722.

Page NM, Butlin DJ, Lomthaisong K, Lowry PJ (2001) The human apolipoprotein L gene cluster: identification, classification, and sites of distribution. Genomics 74:71-78.

Rajagopalan LE, Malter JS (1996) Turnover and translation of in vitro synthesized messenger RNAs in transfected, normal cells. J Biol Chem 271:19871-19876.

Ramirez MM, Kim DD, Duran WN (1996) Protein kinase C modulates microvascular permeability through nitric oxide synthase. Am J Physiol 271:H1702-H1705.

Roux F, Durieu-Trautmann O, Chaverot N, Claire Chaverot, Mailly P, Bourre JM, Strosberg AD, Couraud PO (1994) Regulation of gamma- 
glutamyl transpeptidase and alkaline phosphatase activities in immortalized rat brain microvessel endothelial cells. J Cell Physiol 159:101-113.

Saishin Y, Takahashi K, Melia M, Vinores SA, Campochiaro PA (2003) Inhibition of protein kinase $\mathrm{C}$ decreases prostaglandin-induced breakdown of the blood-retinal barrier. J Cell Physiol 195:210-219.

Sandoval R, Malik AB, Minshall RD, Kouklis P, Ellis CA, Tiruppathi C (2001) $\mathrm{Ca}(2+)$ signalling and PKCalpha activate increased endothelial permeability by disassembly of VE-cadherin junctions. J Physiol (Lond) 533:433-445.

Schneider A, Martin-Villalba A, Weih F, Vogel J, Wirth T, Schwaninger M (1999) NF-kappaB is activated and promotes cell death in focal cerebral ischemia. Nat Med 5:554-559.

Shaw G, Kamen R (1986) A conserved AU sequence from the 3' untranslated region of GM-CSF mRNA mediates selective mRNA degradation. Cell 46:659-667.

Sheng M, Greenberg ME (1990) The regulation and function of c-fos and other immediate early genes in the nervous system. Neuron 4:477-485.

Shigematsu S, Ishida S, Gute DC, Korthuis RJ (2002) Bradykinin-induced proinflammatory signaling mechanisms. Am J Physiol Heart Circ Physiol 283:H2676-H2686.

Siflinger-Birnboim A, Johnson A (2003) Protein kinase C modulates pulmonary endothelial permeability: a paradigm for acute lung injury. Am J Physiol Lung Cell Mol Physiol 284:L435-L451.

Sperk G, Lassmann H, Baran H, Kish SJ, Seitelberger F, Hornykiewicz O (1983) Kainic acid induced seizures: neurochemical and histopathological changes. Neuroscience 10:1301-1315.

Stasek Jr JE, Patterson CE, Garcia JG (1992) Protein kinase C phosphorylates caldesmon77 and vimentin and enhances albumin permeability across cultured bovine pulmonary artery endothelial cell monolayers. J Cell Physiol 153:62-75.

Sukumaran SK, Prasadarao NV (2003) Escherichia coli K1 invasion increases human brain microvascular endothelial cell monolayer permeability by disassembling vascular-endothelial cadherins at tight junctions. J Infect Disease 188:1295-1309.

Thurston G, Maas K, Labarbara A, McLean JW, McDonald DM (2000) Microvascular remodelling in chronic airway inflammation in mice. Clin Exp Pharmacol Physiol 27:836-841.

Tiruppathi C, Malik AB, Del Vecchio PJ, Keese CR, Giaever I (1992) Electrical method for detection of endothelial cell shape change in real time: assessment of endothelial barrier function. Proc Natl Acad Sci USA 89:7919-7923.

Tomanek RJ (1996) Formation of the coronary vasculature: a brief review. Cardiovasc Res 31:E46-E51.
Tomanek RJ, Haung L, Suvarna PR, O’Brien LC, Ratajska A, Sandra A (1996) Coronary vascularization during development in the rat and its relationship to basic fibroblast growth factor. Cardiovasc Res 31:E116-E126.

Tomanek RJ, Ratajska A, Kitten GT, Yue X, Sandra A (1999) Vascular endothelial growth factor expression coincides with coronary vasculogenesis and angiogenesis. Dev Dyn 215:54-61.

Toullec D, Pianetti P, Coste H, Bellevergue P, Grand-Perret T, Ajakane M, Baudet V, Boissin P, Boursier E, Loriolle F (1991) The bisindolylmaleimide GF $109203 \mathrm{X}$ is a potent and selective inhibitor of protein kinase C. J Biol Chem 266:15771-15781.

van Soeren MH, Diehl-Jones WL, Maykut RJ, Haddara WM (2000) Pathophysiology and implications for treatment of acute respiratory distress syndrome. AACN Clin Issues 11:179-197.

Verin AD, Liu F, Bogatcheva N, Borbiev T, Hershenson MB, Wang P, Garcia JG (2000) Role of ras-dependent ERK activation in phorbol esterinduced endothelial cell barrier dysfunction. Am J Physiol Lung Cell Mol Physiol 279:L360-L370.

Vogel SM, Easington CR, Minshall RD, Minshall N, Tiruppathi C, Hollenberg SM, Parrillo JE, Malik AB (2001) Evidence of transcellular permeability pathway in microvessels. Microvasc Res 61:87-101.

Walton M, Henderson C, Mason-Parker S, Lawlor P, Abraham WC, Bilkey D, Dragunow M (1999) Immediate early gene transcription and synaptic modulation. J Neurosci Res 58:96-106.

Wang X, Sato R, Brown MS, Hua X, Goldstein JL (1994) SREBP-1, a membrane-bound transcription factor released by sterol-regulated proteolysis. Cell 77:53-62.

Woodward WR, Nishi R, Meschul CK, Williams TE, Coulombe M, Eckenstein FP (1992) Nuclear and cytoplasmic localization of basic fibroblast growth factor in astocytes and CA2 hippocampal neurons. J Neurosci 12:142-152.

Wu HM, Yuan Y, Zawieja DC, Tinsley J, Granger HJ (1999) Role of phospholipase $\mathrm{C}$, protein kinase $\mathrm{C}$, and calcium in VEGF-induced venular hyperpermeability. Am J Physiol 276:H535-H542.

Yamagata K, Andreasson KI, Kaufmann WE, Barnes CA, Worley PF (1993) Expression of a mitogen-inducible cyclooxygenase in brain neurons: regulation by synaptic activity and glucocorticoids. Neuron 11:371-386.

Yuan SY (2002) Protein kinase signaling in the modulation of microvascular permeability. Vascul Pharmacol 39:213-223.

Zhao Y, Davis HW (1998) Hydrogen peroxide-induced cytoskeletal rearrangement in cultured pulmonary endothelial cells. J Cell Physiol 174: $370-379$. 